\title{
وحدة الديني والفلسفي في مشروع "أبو يعرب المرزوقي" الحضاري
}

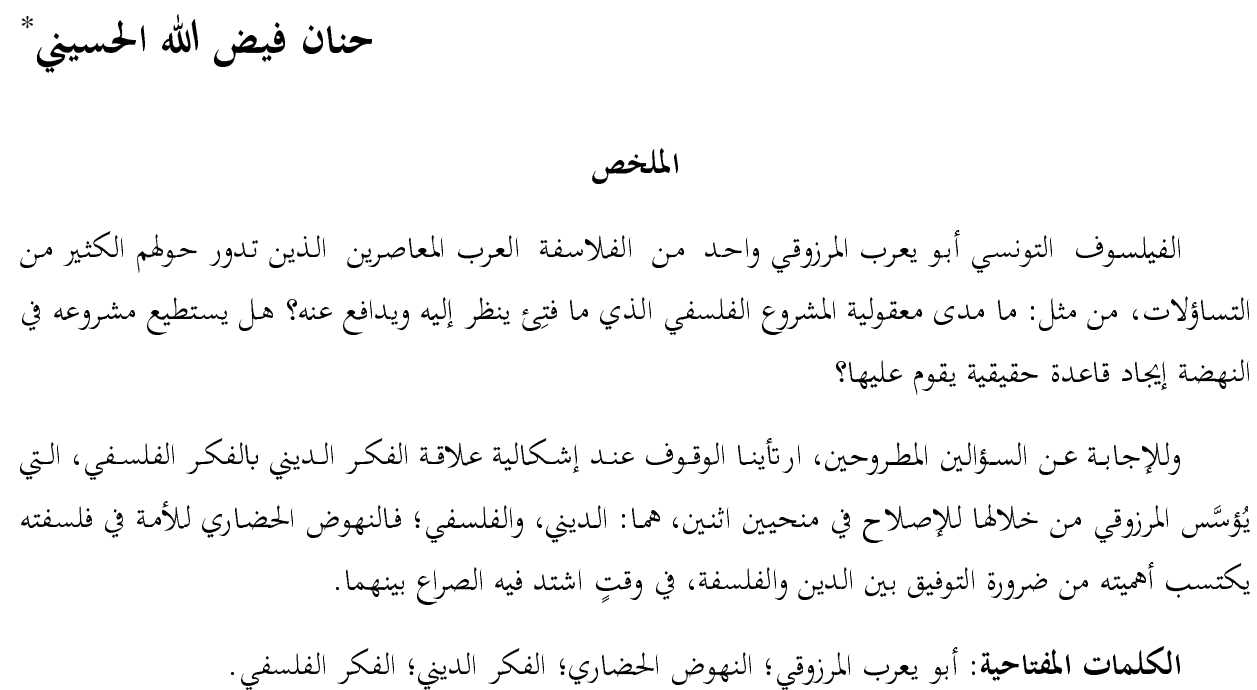

\section{Unity of the Religious and Philosophical in Al-Marzouki}

\section{Civilizaitonal Project}

\begin{abstract}
Abou Yaareb Al-Mazouki is a contemporary Tunisian philosopher and a controversial scholar. Questions about his philosophical project pertain to how realistic is this project, and how solid is its base

To answer these questions, this paper examines the relationship between religious and philosophical thoughts. Al-Mazouki emphasizes that the path to the prospective reform has to pass through both religious and philosophical reforms. The civilizational revival of the ummah in his philosophy has its importance from the need to reconcile religion and philosophy, at a time of intense conflict between them.

Keywords: Abou Yaareb Al-Mazouki; Civilizational revival; Religious thought, Philosophical thought.

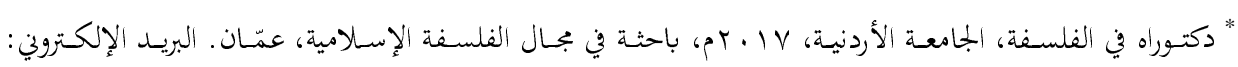

$$
\begin{aligned}
& \text { hanan_alhuss@yahoo.com }
\end{aligned}
$$

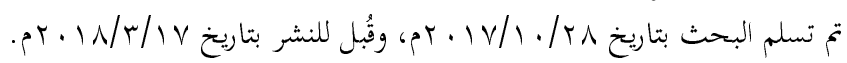




\section{مقدمة:}

إن الواقع الأليم الذي تعيشه الأُمَّة العربية الإسلامية، من حيث الاصطراع القائم بين

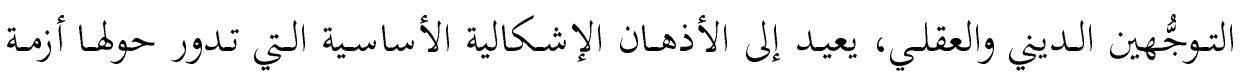

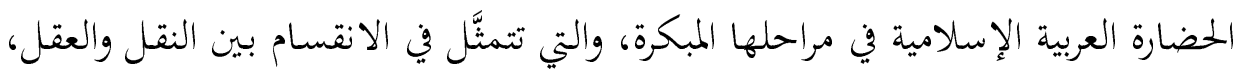

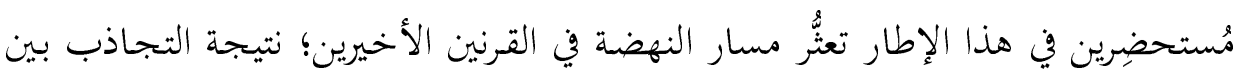
الديني والعقلي في رسم إطار التجديد.

ومـن الجـدير بالذذكر أن الفصام بـين الدين والفلسفة قـد تكرَّر في التـاريخ الفكري

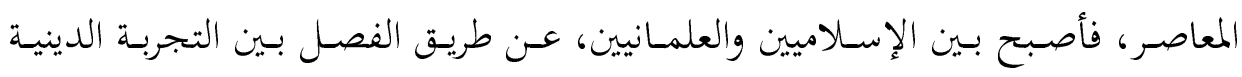

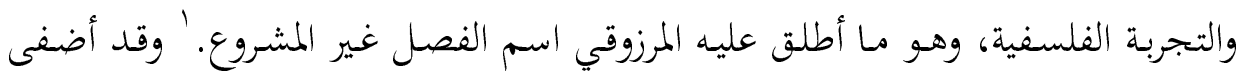

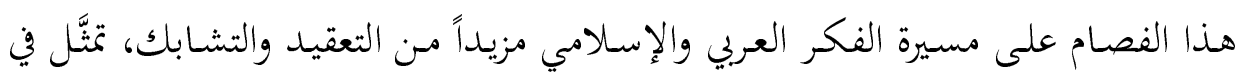
الجمود الذي أصاب حرية الفكر لديهم.

يهـدف هـا البحثث إلى إلقـاء الضوء على إشكالية الوحدة بين الديني والفلسفي لدى المرزوقي؛ وذلك بفهم الإشكالات المرتبطة بهما نتيجة التحريف الذي أصاب كلّاً منهما، فضلاً عن إبراز دور المرزوقي في التوحيد بين الدين والفلسفة، بوصف ذلك ذلك خطوة

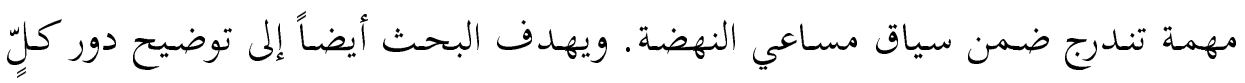

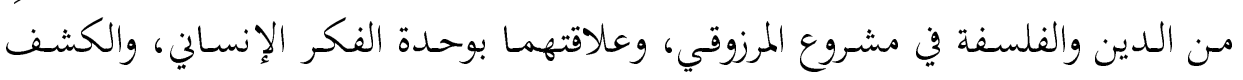

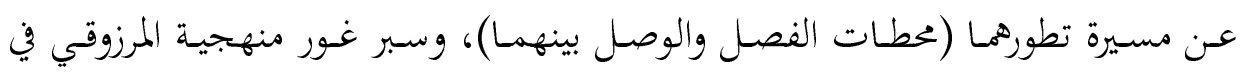

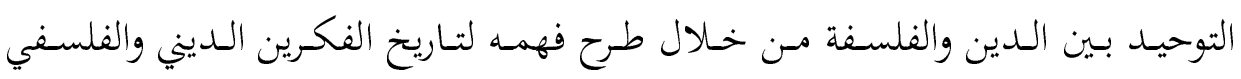
وتطورهما.

وتنبع أهمية البحث من جوانب عدَّة، أهمها: محتوى البحث الذي يعرض لصراع قديم

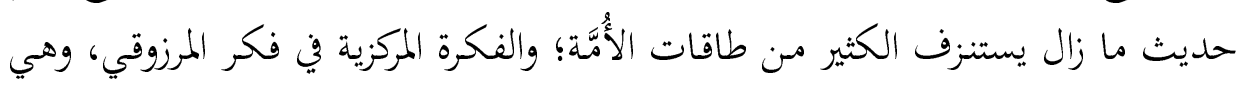

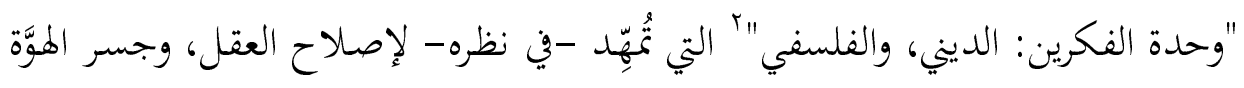

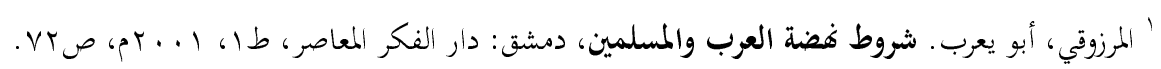

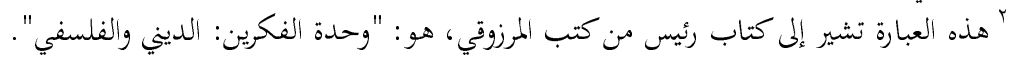




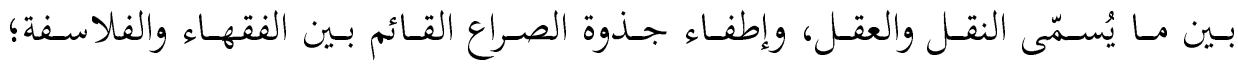

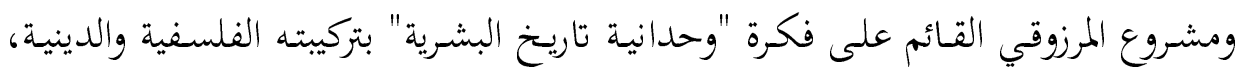

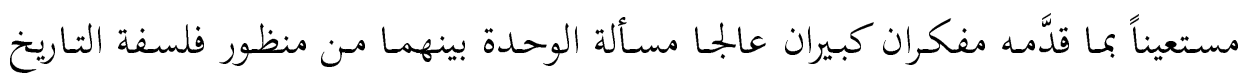
وفلسفة الدين، وهما: ابن خلدون، وابن تيمية.

\section{دلالة المصطلحات:}

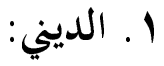

عرَّف إخوان الصفا الدين بأنه "شيئان اثنان: أحدهما هو الأصل وملاك الاعتقاد في

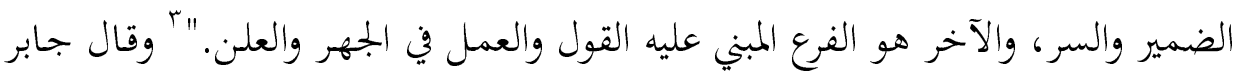

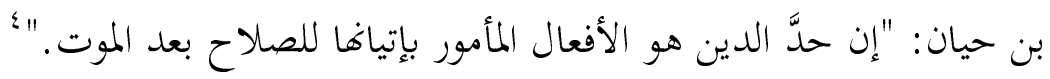

أمّا في المعجم الفلسفي فِإن "الدين يُعبّرب عن العلاقة بين المطلق في إطلاقه والمحدود

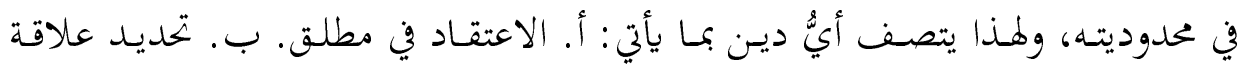

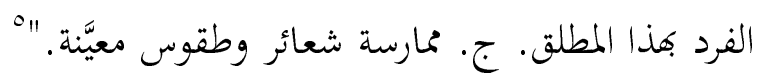

و تأسيساً على ذلك، فقد مثَّل الدين رؤية للوجود والذات والمآل، وهي رؤية تنتظم

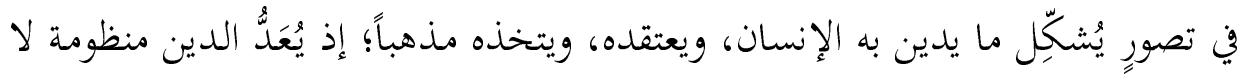

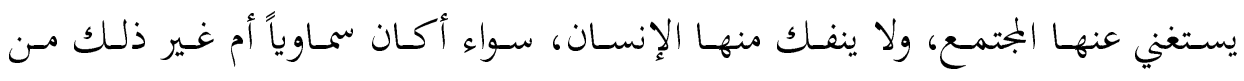
التصورات الوضعية -وإن كانت الأديان السماوية هي مجال بحثنا- علماً أن مصدر المعرفة الإنساء في الدين هو الوحي الثابت الذي لا يحتمل إلا التصديق.

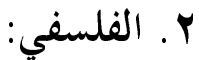

لم يتفق الفلاسفة على تعريف اصطلاحي واحد للفلسفة؛ إذ عرَّفها كل فيلسوف من

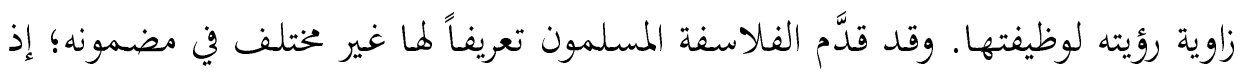

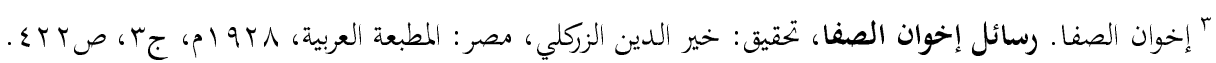

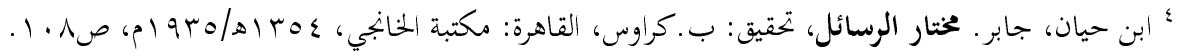

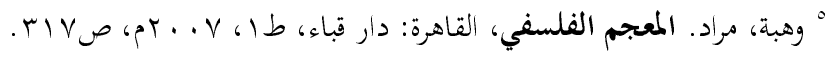




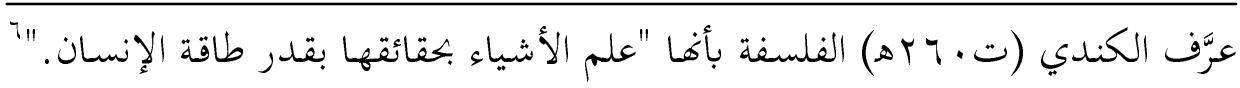

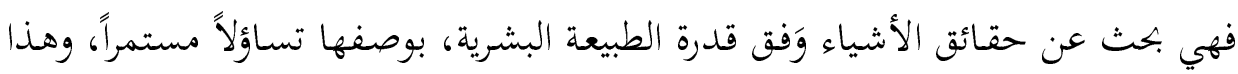

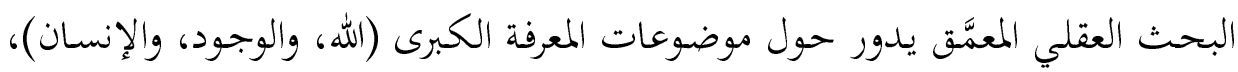

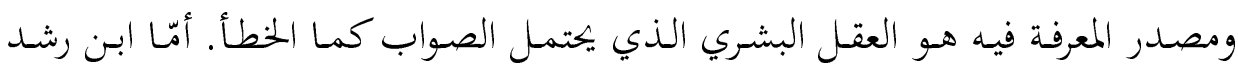

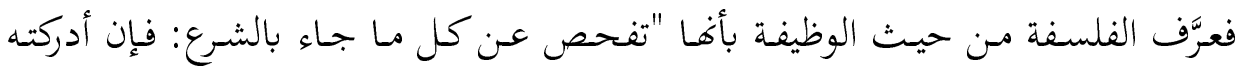

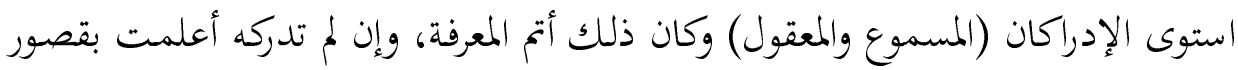

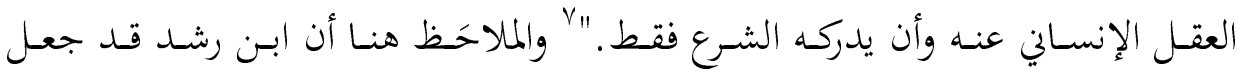

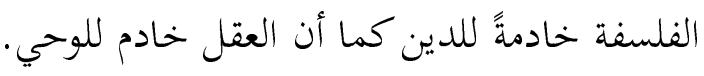

\section{ب. الفكر الديني والفكر الفلسفي:}

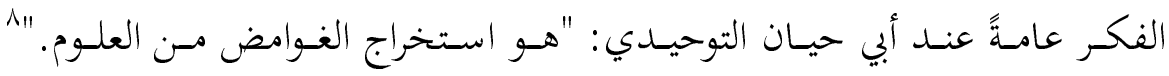

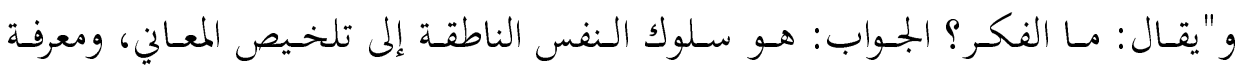

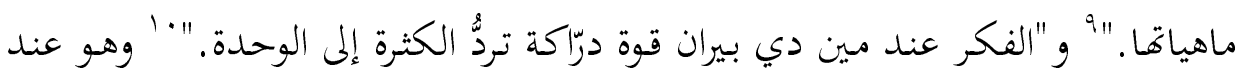

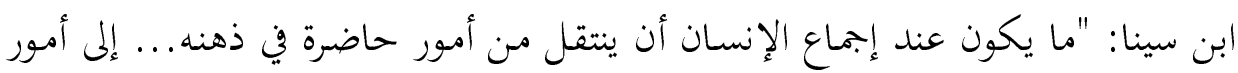

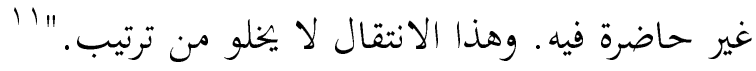

وعلى هذا، فإن للفكرين الديني والفلسفي صلةً بحصيلة إنتاج الأمم المعري من الدين

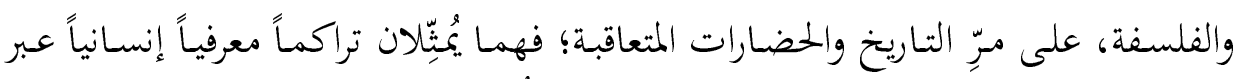

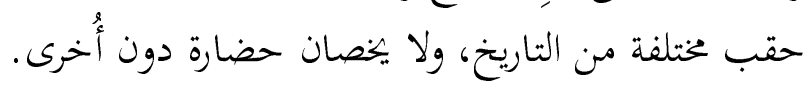

وفي هذا السياق، ينطلق الفكر الديني (إنتاج العقل الموحى إليه) مـ علوم الشريعة

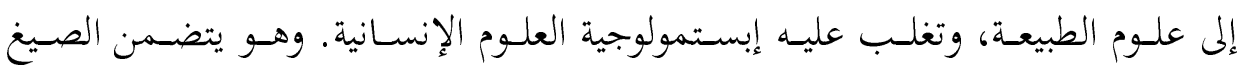
" الكندي، يعقوب بن إسحاق. رسائل الكندي الفلسفية، تحقيق: محمد عبد الهادي أبو ريدة، القاهرة: دار الفكر

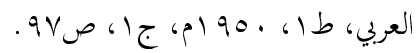

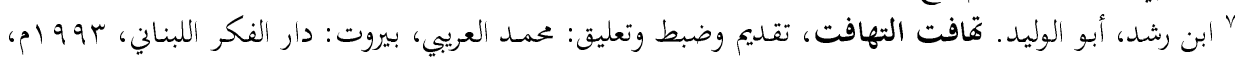
صזي بر.

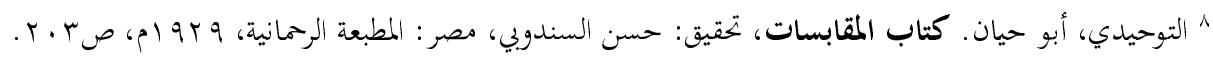

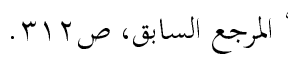

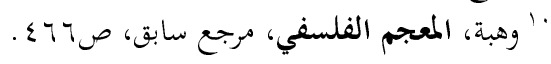

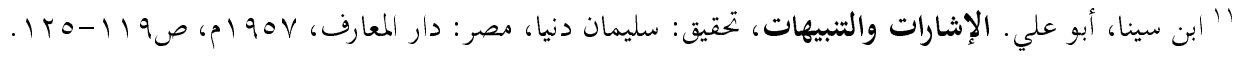


المختلفة لفهم النص الديني ودراسته، من حيث هو فهم للتعاليم الإلهية -إذا كان الدين

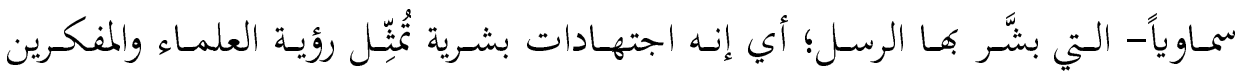

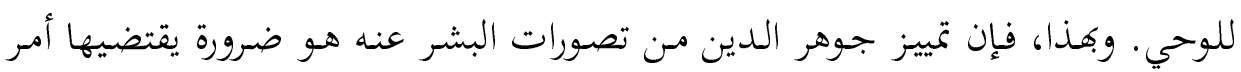

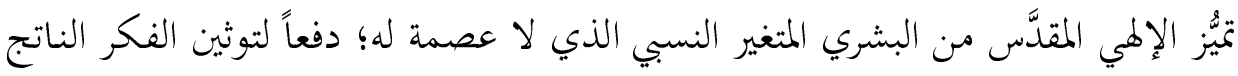
من الفهم.

أمّا الفكر الفلسفي (العقل بحسب تطوره الطبيعي) فينطلق مـن علوم الطبيعة إلى

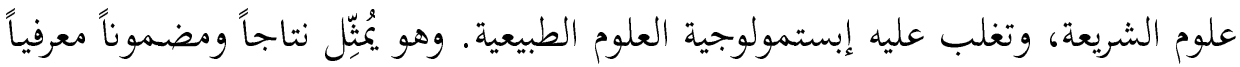

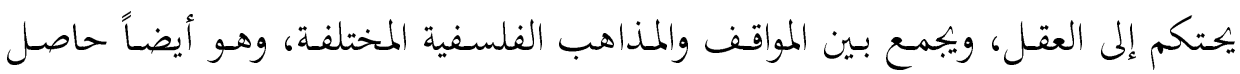

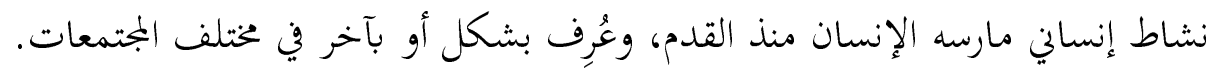
والمنهج في الفكر الديني تحليلي، وذلك باعتماده على تفسير نصوص الدين وفهمها،

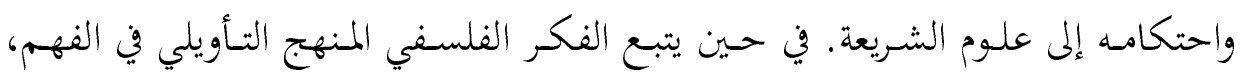

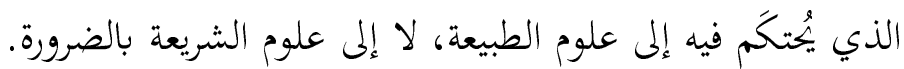

وقد عرض المرزوقي لمضمون الفكرين، مُبيّناً أن الفكر الديني نشاط إنساني يتعلَّق

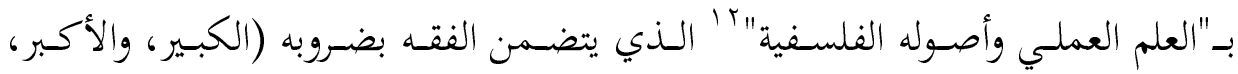

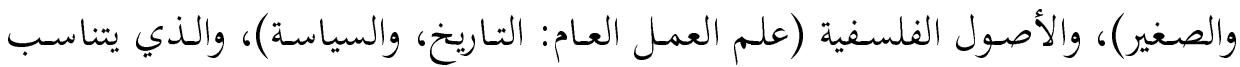

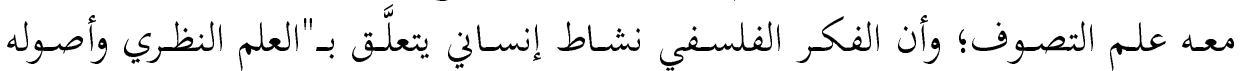

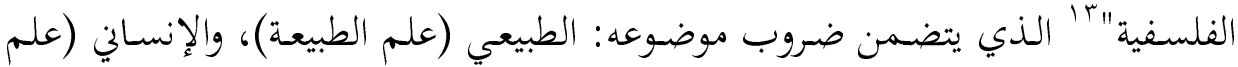

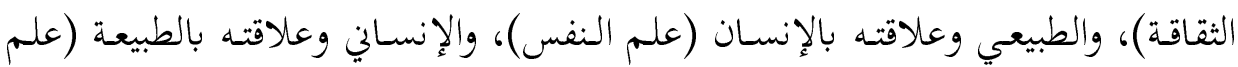

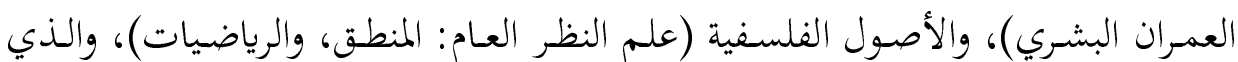

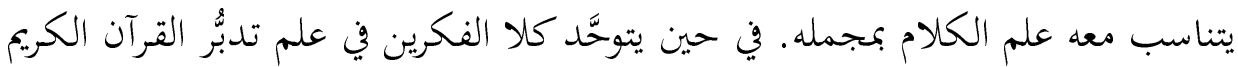
بوصفه النص المؤسس والمعيار لكل النشاط الإنساني. ولا شكّ في أن تصنيف المرزوقي لمضمون هذين الفكرين قد انبثق من رؤيته للنشاط

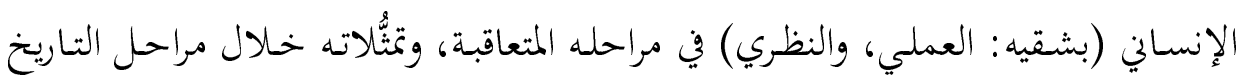
المختلفة، فجاء المضمون على هذا التنوع والاختلاف.

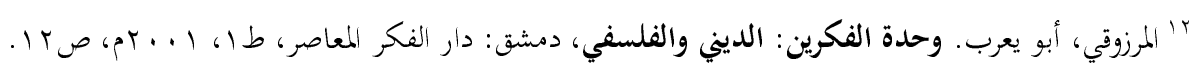

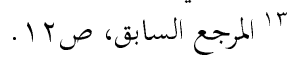




\section{المرزوقي وعلاقة أفكاره بالتراث:}

إن العناية بمسألة الوحدة بين الدين والفلسفة ليست أمراً جديداً طارئاً؛ فهي قديمة قِـدَم التنـاقض بينهمـا. وقـد حسدث الاقـتران بـين الـدين والفلسـفة في عصر الوثنيـة حسين

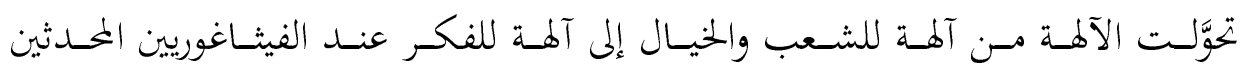

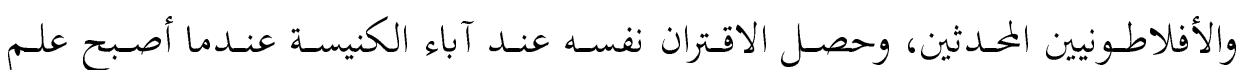
اللاهوت هو الدين المصحوب بالوعي والفكر الذي اكتمل بالتوحيد بين الدين والفلسفة

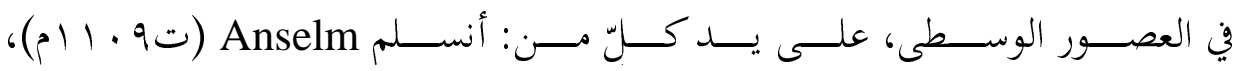

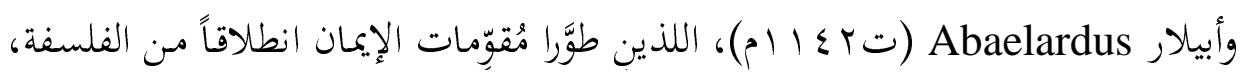

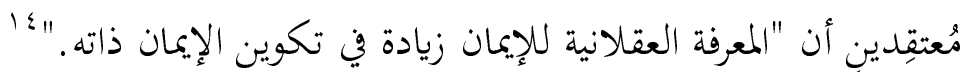

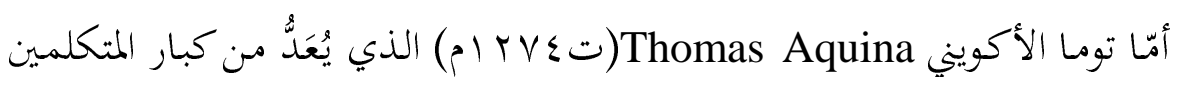

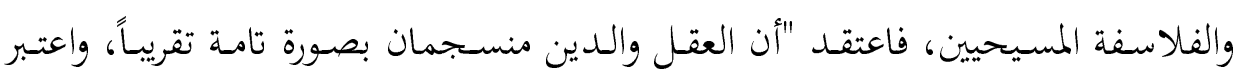

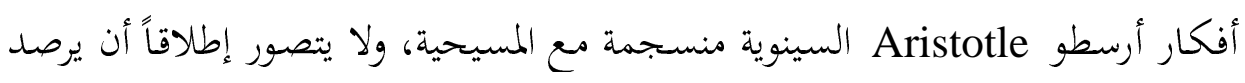
أحد أيَّ تحافت بين أهداف أبحاثه الفلسفية وأهداف أبحاثه الكلامية."

وقد سبقت ذلك محاولات عدَّة للتوحيد بين الفكرين خلال حقب زمنية مختلفة،

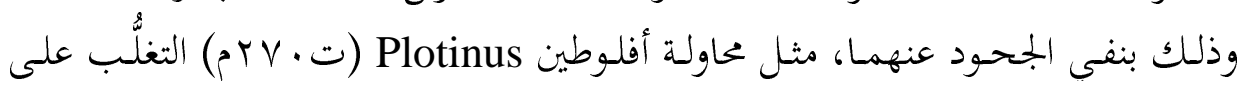

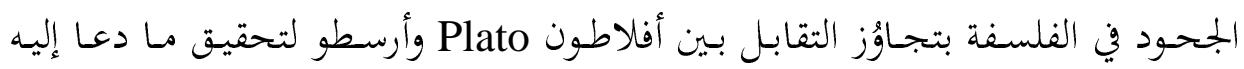

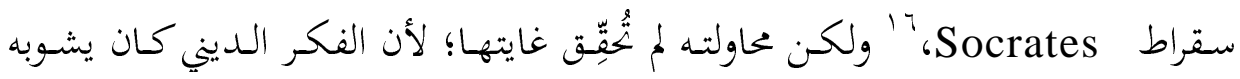

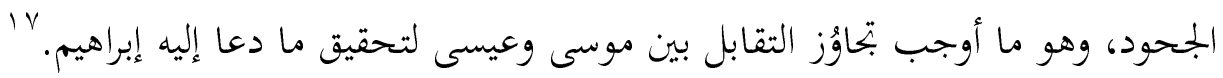
؛' هيجل. جدلية الدين والتنوير "من دروس فلسفة الدين لهيجل"، ترجمة: أبو يعرب المرزوقي، أبو ظبي: كلمة،

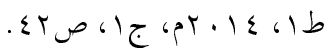

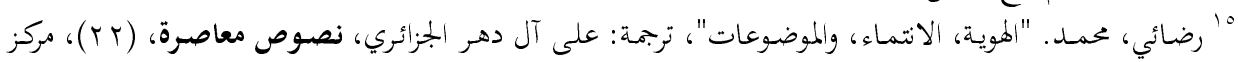

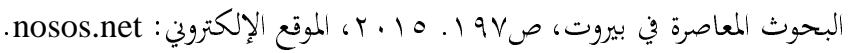

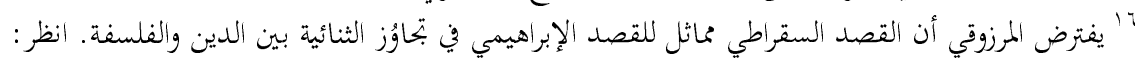

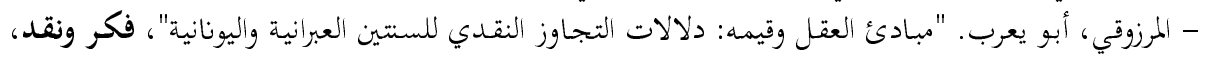

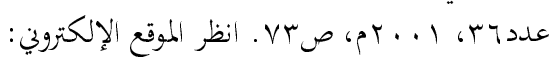

- www.aljabriabed.net/n36_03marzuki.htm

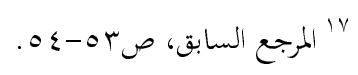




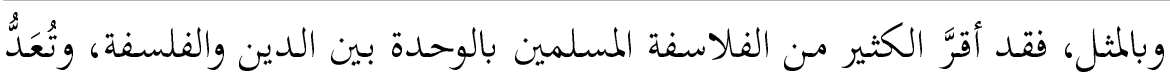

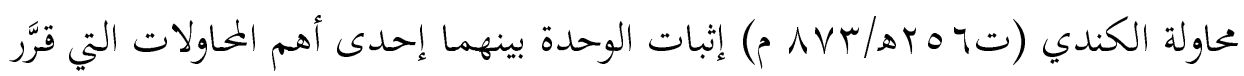

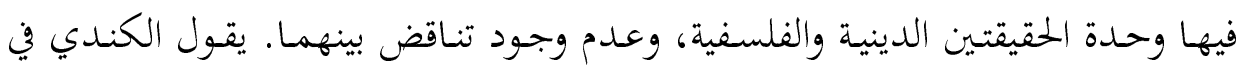

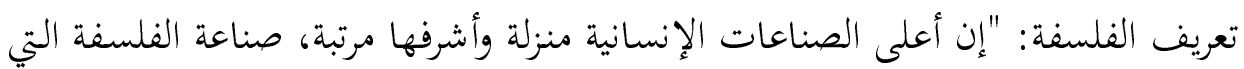

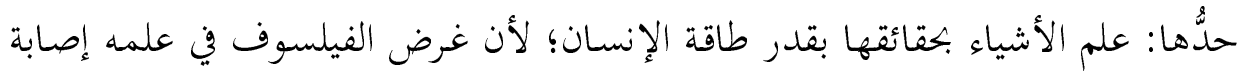

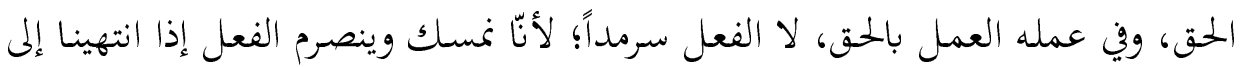

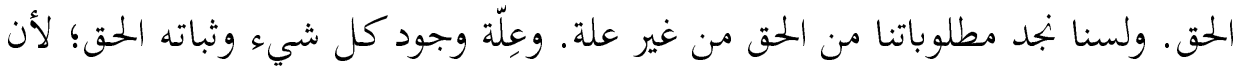

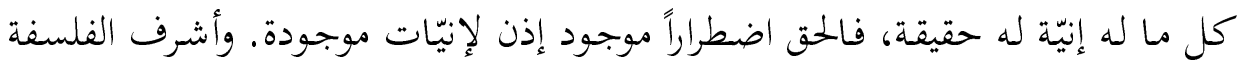

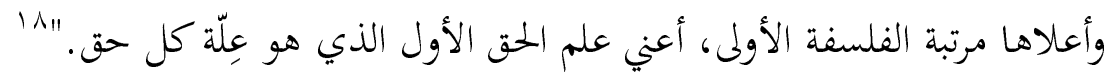
وينطلق الكنـدي في مسألة التوحيـد بـين الفلسفة والـدين مـن أمـين؛ الأول: توافُقق

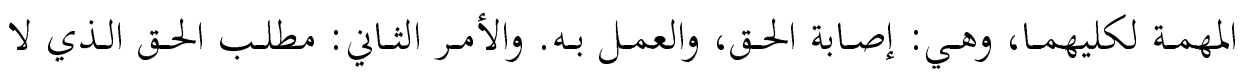

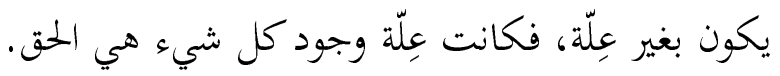
ثم تلا ذلك محاولة ابن رشد (تع 90 هـ/91 1 ام) التوفيق بين الفلسفة والدين، في

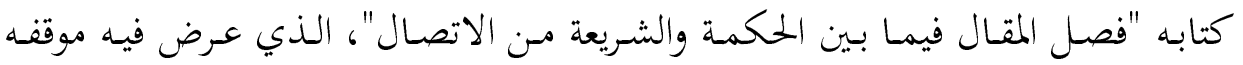

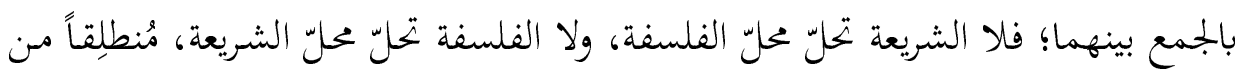

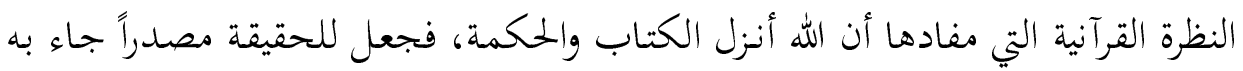

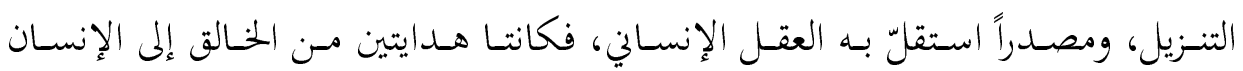

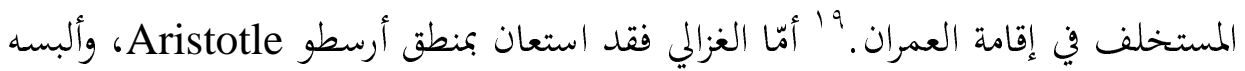
لباساً إسلامياً. وقد تَسلَّح بعض الأصوليين بالفلسفة بشكل أو بآخر، وبتلّى ذلك في مصسنفات

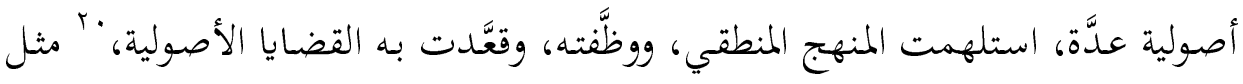

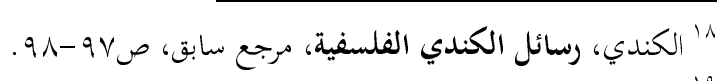

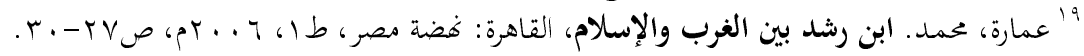

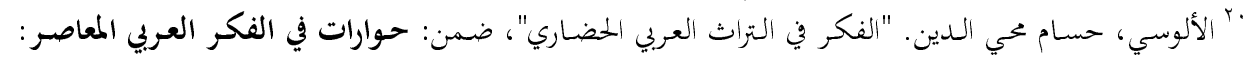

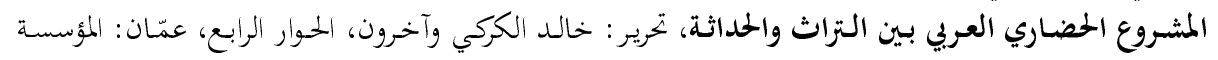




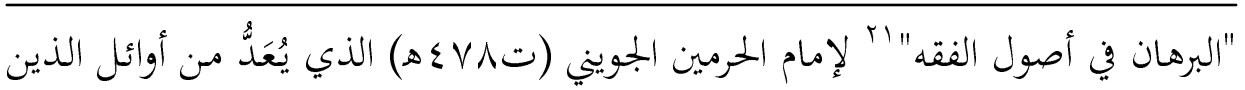

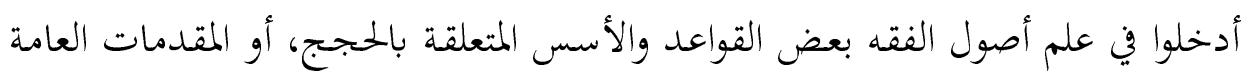
التي عرضها أرسطو Aristotle في كتاباته المنطقية.

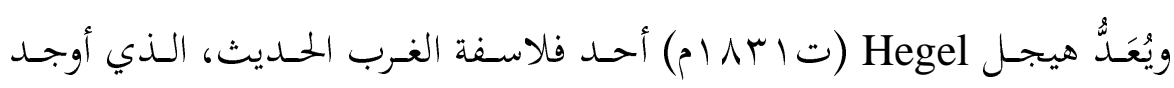

علاقة بين الدين والفلسفة -على غير عادة الفلاسفة الذين سبقوه- حين تناول الظاهرة الدينية بالتمحيص والتحليل، وذلك بدراسته تطور الوعي الديني للإنسان من خلال تتبُّع مسار الأديان على مرِّ التاريخ؛ إذ قال: "لنجد خهلال التاريخ أن الدين والفلسفة كثيراً مـا

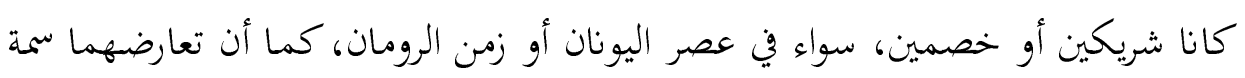

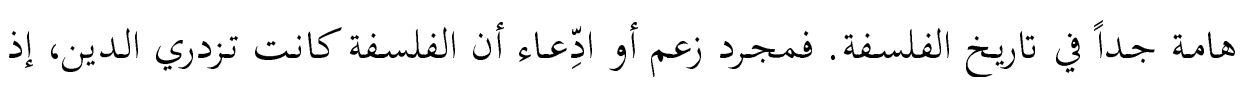

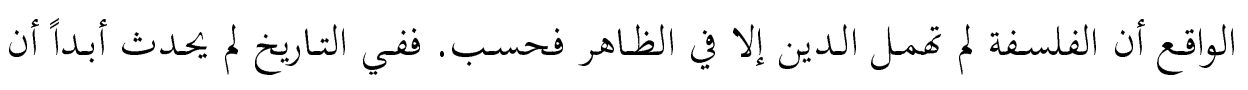
ترك الواحد منهما الآخر دون أن يمسَّه.

إن موقف هيجل من علاقة الفلسفة بالدين إيجابي؛ إذ رأى أن الفلسفة تشارك الدين في المضمون والحاجـة والاهتمام، فقـال: "إن موضسوع الدين وكذلك الفلسفة هو الحقيقة

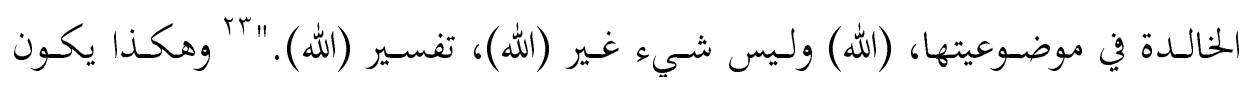
هيجل قد رسم معالم المطابقة بين هذين الفكرين. و تأسيساً على ذلك، فإن محاولات التوفيق بين الفلسفة والدين لدى المرزوقي ليست خارجة عن مألوف التاريخ الإسلامي وما سبقه من محاولات؛ فالدين والفلسفة متحدان في المضمون والحاجة والهمّ، ومختلفان في الشكل.

بr الجويني، أبو المعالي. البرهان في أصول الفقه، تققيق: عبد العظيم الديب، الإسكندرية: دار الوفاء، طع، 9919 ام، ص.r-r rr هيجل، جورج فريدرك. محاضرات هيجل في في تاريخ الفلسفة، ترجمة: إمام عبد الفتاح إمام، القاهرة: مكتبة مدبولي،

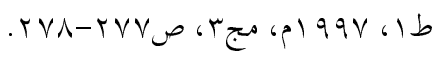

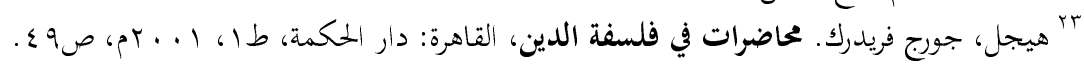




\section{أولاً: إشكالية الوحدة بين الديني والفلسفي}

تكمن هذه الإشكالية في أمرين؛ أوهما: رؤية بعض الأصوليين الإسلاميين المُتمثِّة في استحالة التوفيـق بـين الفكـر الفلسـفي والفكـر الـديني؛ مـا دفعهمم إلى الحلكـم بإلغـاء

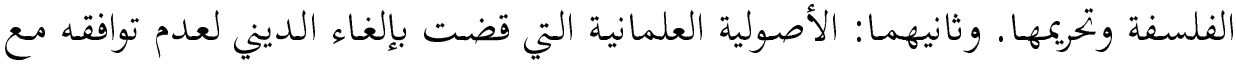
منطق العقل؛ فكلاهما يقول بالتنافي، وقوهما هو جوهر الاختلاف. ومسن الجسدير ذكره أن التحريف الـذي طرأ على الحنيفيـة المحضسة في تاريـخ الفلسفة

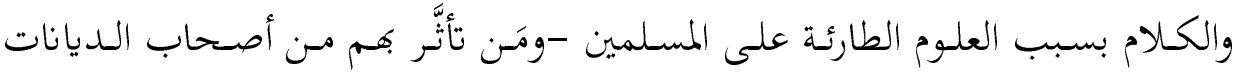

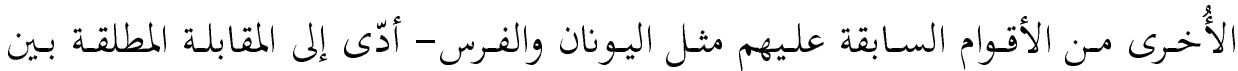

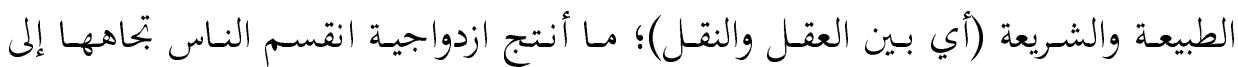

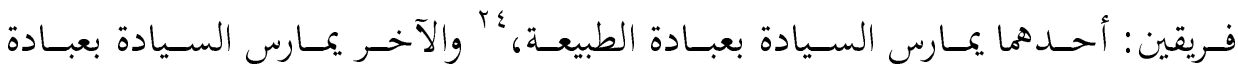
ro. الشريعة.

أمّا الفريق الأول الذي يُمثِّل الأصولية العلمانية فقد عمد إلى إلغاء الديني ونبذه بحجة

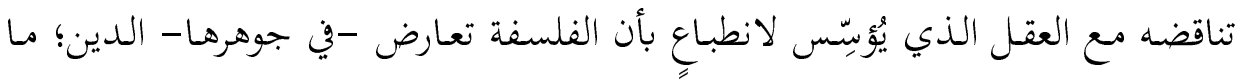
أوجـد رؤيـة عدائية للفلسفة بجاه الدين. وأمّا الفريق الثاني الذي يُمثِّل الأصسولية الدينيـة فأظهر عدم الرغبة في تناول الظاهرة الدينية بالنقد والتمحيص استناداً إلى ضرورة الالتزام بواجب الاحترام والتقديس، فضلاً عن بتحاهُل رجال الدين الأفكار الفلسفية وتحرُّجهم من

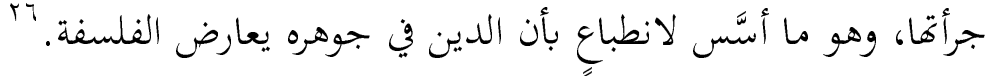

وكانت النتيجة أن تحوَّلت الصياغات الكلامية المتولِّدة في كالا الفكرين (الفلسفي،

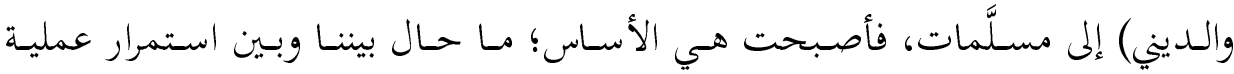
؛' يرى المرزوقي أن مصطلح "عبادة الطبيعة" لا يقتصر على مظاهر الطبيعة، وإنما يشمل ممارسة التقديس لمقولات أرسطو في الطبيعة.

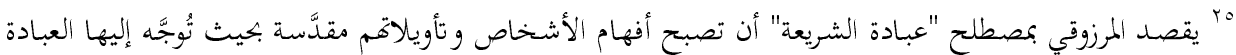
من دون الله.

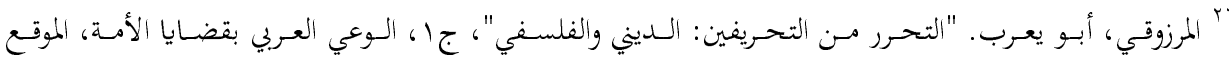
الإلكتروني: https:/abouyaarebmarzouki.wordpress.com. 


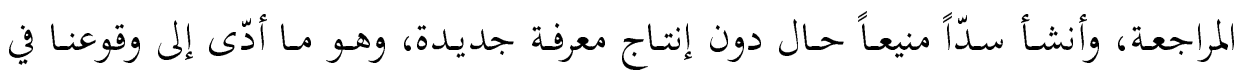

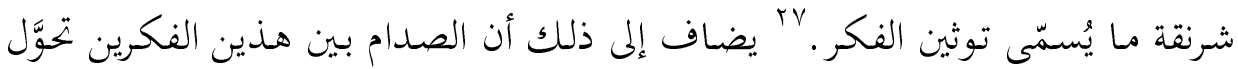

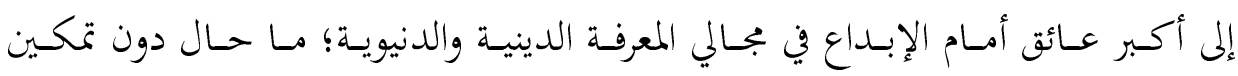
المسلمين من أدوات الاستخلاف - وكذا الشهادة- على العالمين.

وقـد ظهرت تمشثُلات تلـك الإشـكالية في المـأزق الـذي يعيشـه حاضـر فكـر النهضـة

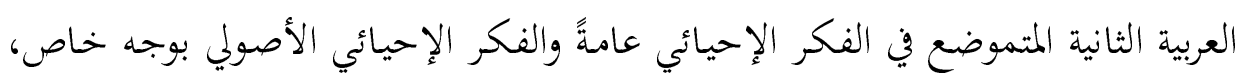

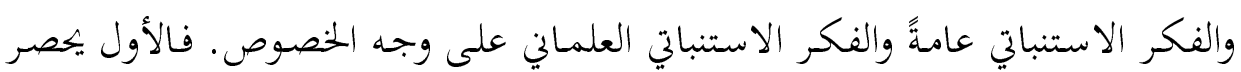

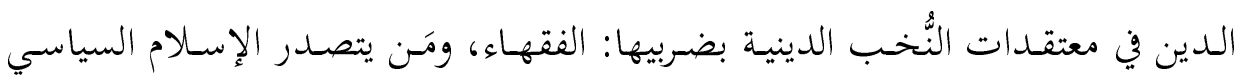
اليوم. والثاني يقصر الفلسفة على النُخب الائكية (العلمانية) بضربيها: الوضعية النظرية

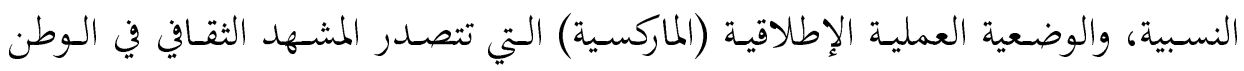
العربي.

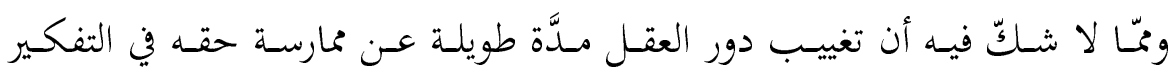

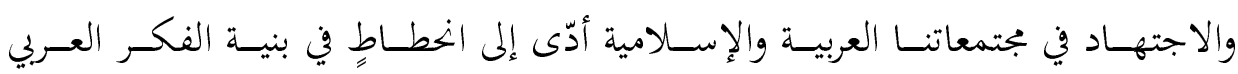

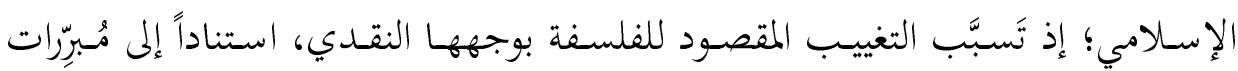

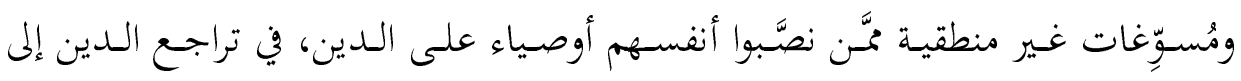

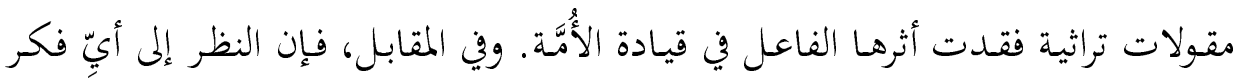
ديني بوصفه فكراً ظلامياً رجعياً -بحسب أدعياء التنوير والتثوير على نمط التنوير الغربي -

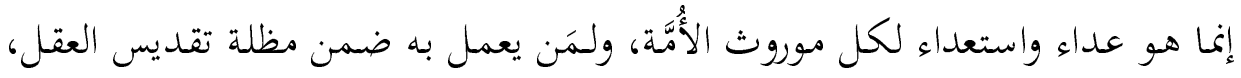

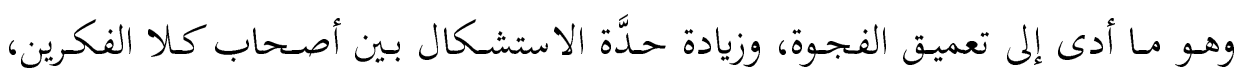

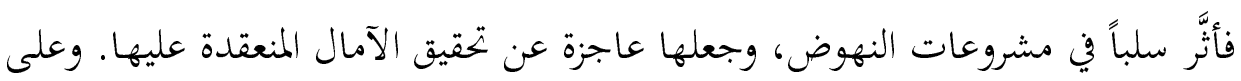

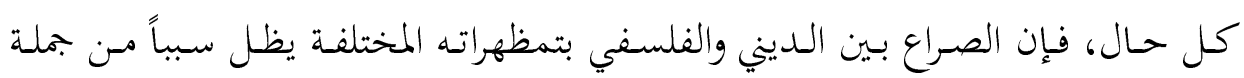
أسبابٍ لما تداعياتما وانعكاساتما الخطيرة على المنطقة.

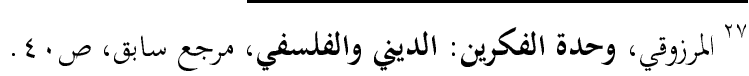

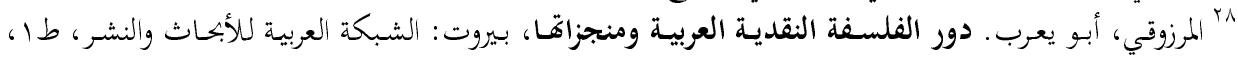




\section{ثانياً: علاقة الفكر الديني بالفكر الفلسفي}

تقتضي الوحدة بين الفكر الديني والفكر الفلسفي فهم العلاقة بين هذين الفكرين

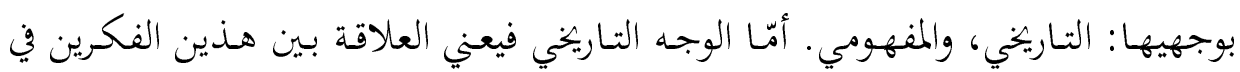

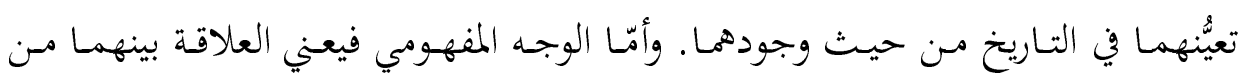
حيث الماهية.

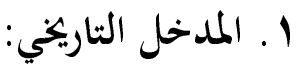

حصر المرزوقي في هـا المداخل المُعِوِقات التي تقف حائلاً أمام فهـم علاقة الفكر

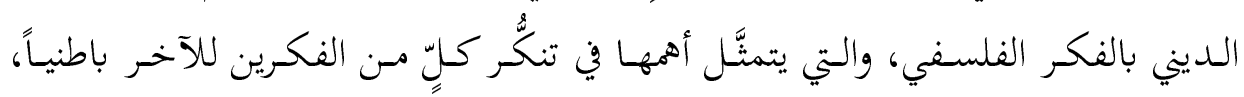
والعداء البادي منهما ظاهرياً لدى المتكلمين باسميهما.

لقد وُِجـد العـداء بين الدين والفلسفة نتيجة التنـافس بين هـذين الفكرين؛ بامتلاك سلطة التوشُط بين الناس والحكام من حيث علاقة كلِّ منهما بالسلطة الروحية والسلطة

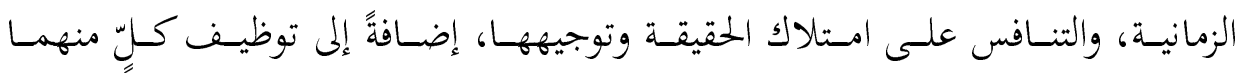

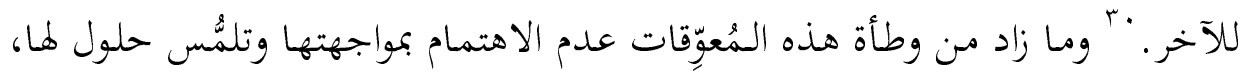

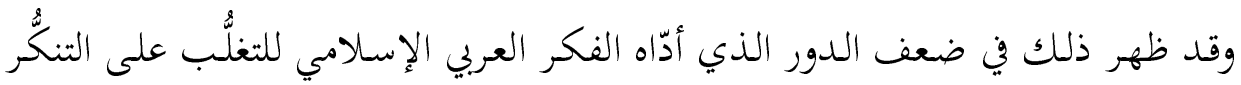

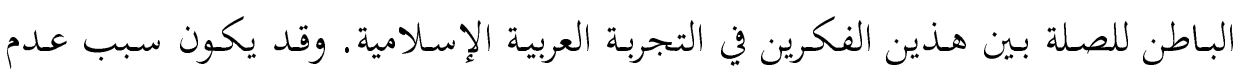

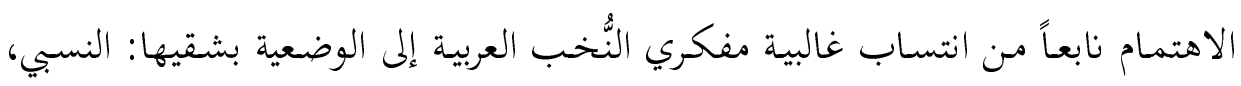

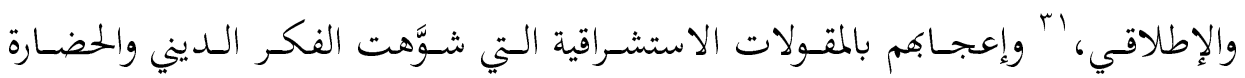

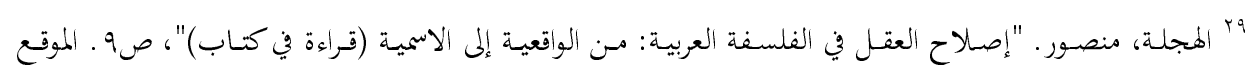

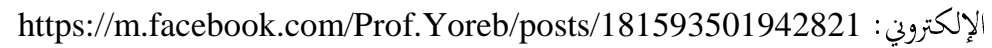

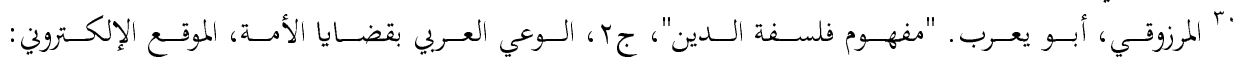
.https:/.abouyaarebmarzouki.wordpress.com

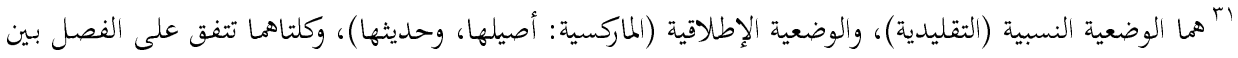

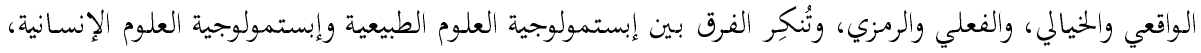


الإسهلامية، فضـالًا عن الوضع المزري الذي وصلت إليه حضسارتنا على مستوى أحداث

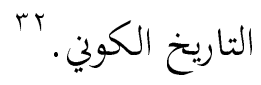

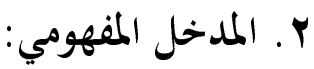

حـدَّد المرزوقي في هـذا المـدخل العناصـر المفهوميـة الجامعـة بــن الفكـرين الـديني

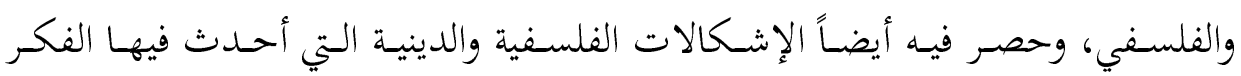

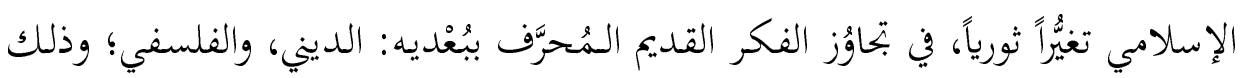

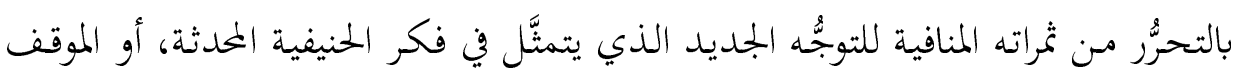

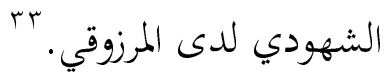

وقـد انبــق عسن هـذين السوجهين أمسران؛ الأول: صسياغة الأسـاس السذي بُسني عليسه التوحيد، والثـاني: إبراز دور الفكر النقـدي في بحـاؤز الإشكالات التي حـدثت على مـرّ التاريخ وحقبه المتلاحقة، تُمثَّالًا في الحنيفية المحدثة.

ثالثاً: مسيرة تطور وحدة كلٍ من الدين والفلسفة (عططات الفصل والوصل بينهما) لقد اعتقد المرزوقي أن الوحدة الشهودية لن تتحقق من دون الربط بين مبادئ الفكر الفلسفي والفكر الديني، وبيَّن ما طرأ على مسيرة وحدةما من حيث الشهود والجحودة، وما رافق ذلك من إشكالات فلسفية على مستوى تاريخ النظريات الفلسفية (الوسيطة،

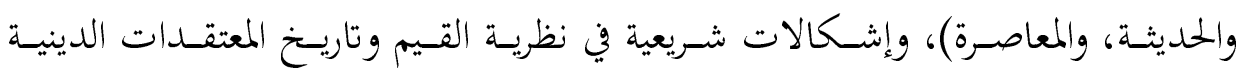

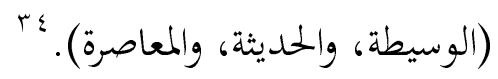

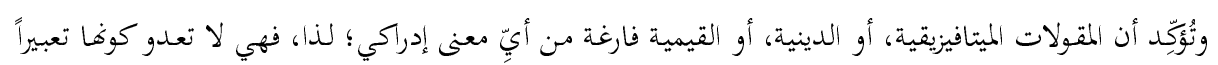

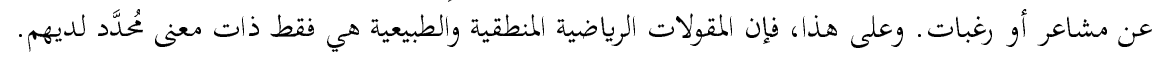

$$
\begin{aligned}
& \text { rr }{ }^{r r}
\end{aligned}
$$

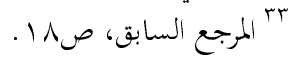

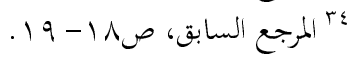




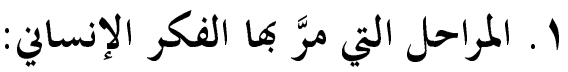

مرَّ الفكر الإنساني بمراحل متعددة متداخلة أوصلته إلى صيغته الفلسفية والدينية التي

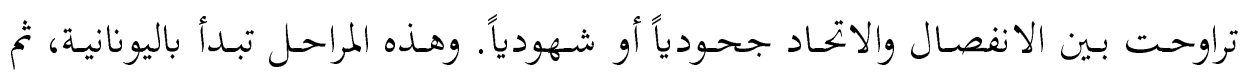
المرحلة الهلنستية، فالمرحلة العربية الإسلامية (مناط بحثنا) التي مهَّدت للمرحلتين التاليتين: الحديثة، ثم المعاصرة.

وقد اقترح المرزوقي سبيلاً لفهم الوحسدة بين الفكرين الديني والفلسفي، يتمثَّل في

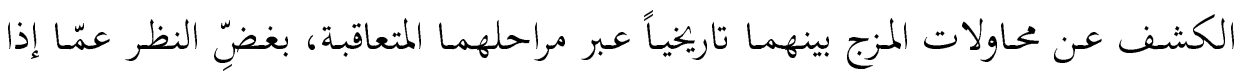

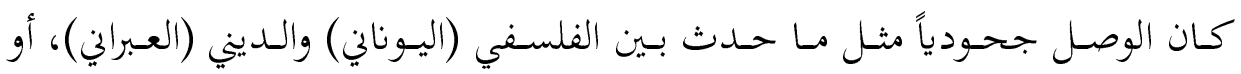
شهودياً كما حدث في الحضارة الإسلامية.

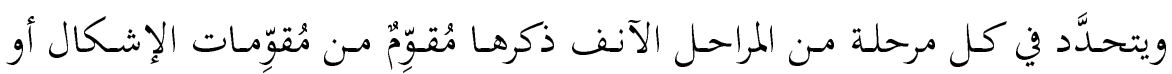
الصراع بين ضربين من ضروب التوحيد بين الفكرين الفلسفي والديني: التوحيد الحلولي

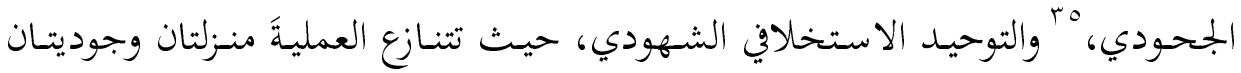
للإنسان، ومنهجان معرفيان في مجال القيم جميعها.

ويظهر الصراع بينهما في مسار التاريخ الإنساني؛ وذلك أن القيم السائدة المسيطرة

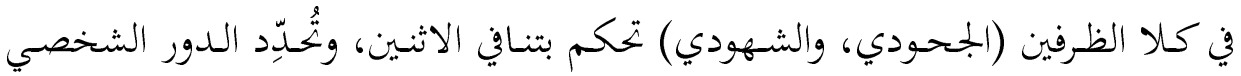

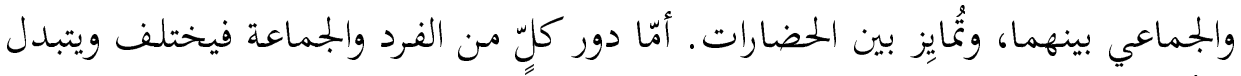

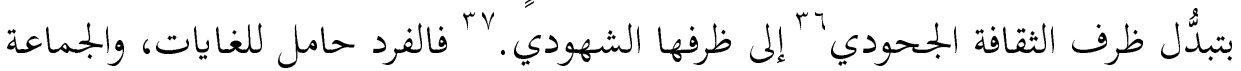

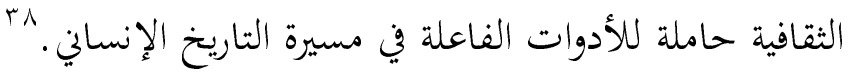
إن منطق المراحل التي مـرَّ بهـا الفكر الإنسـاني -باستثناء المرحلـة الوسيطة- يعـاني

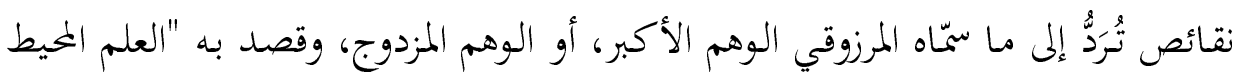

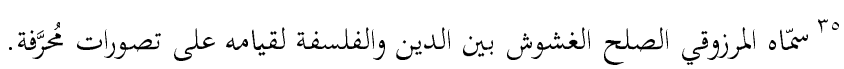

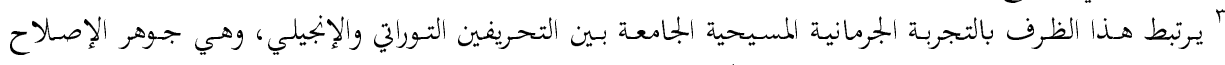
البروتستانتي، وجوهر صياغته الفلسفية الذي تُمَّكَّل في المثالية الألمانية.

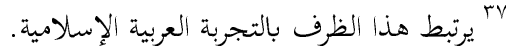

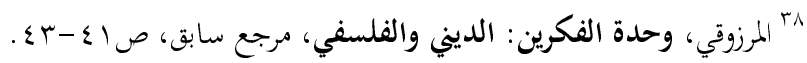




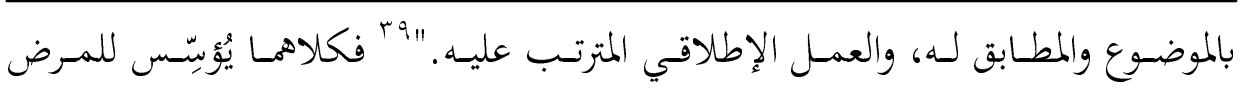

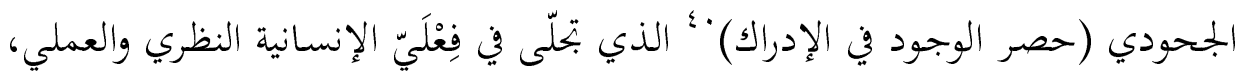
وما يتبعهما من قيم جمالية ووجودية.

\section{r. دور التجربة العربية الإسلامية في تجاؤز إنكالية العداء بين الفكرين الديني}

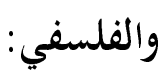

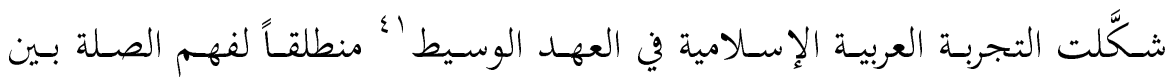

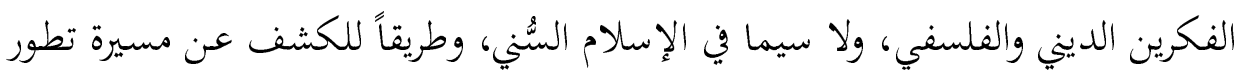

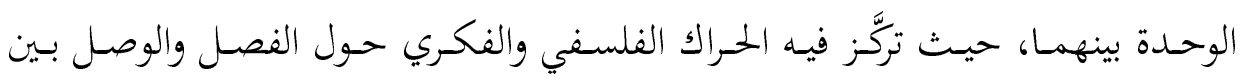

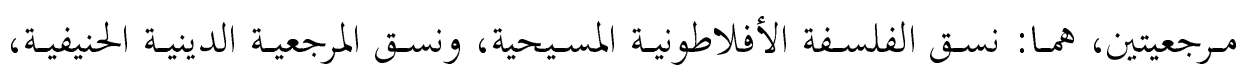
وأصبح هو الطاغي بين أصحاب الظاهر والباطن.

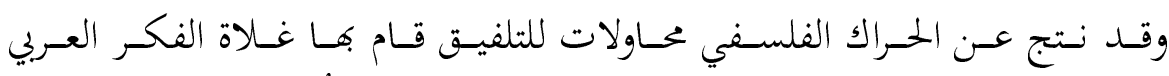

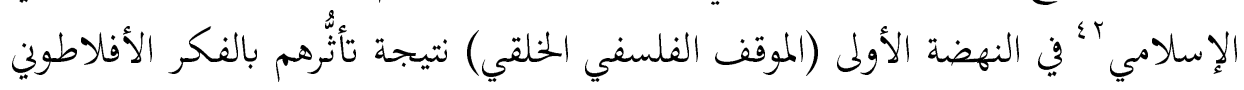

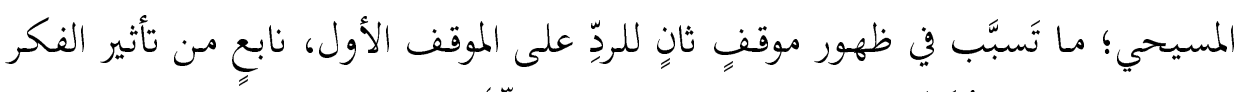

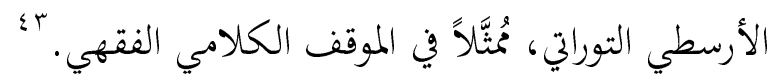

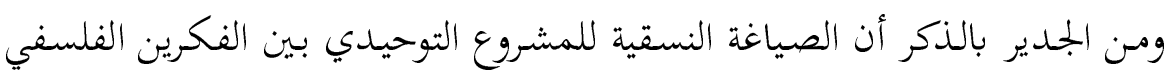

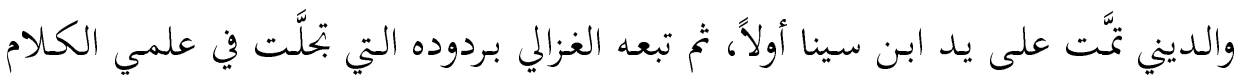

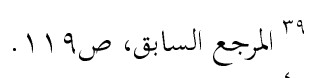
"ينتج عن حصر الوجود في الإدراك مرض الحلولية (حلول النسبي في المطلق)، ومرض الوصولية (وصول النسبي إلى المطلق، أو وصول الإنسان إلى الاتحاد مع اللهاد.

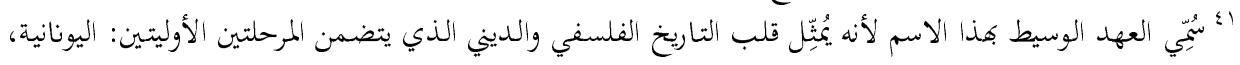

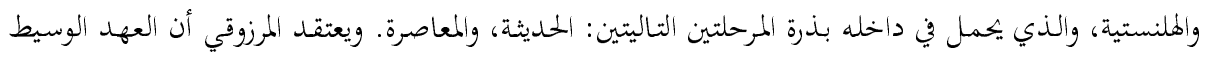

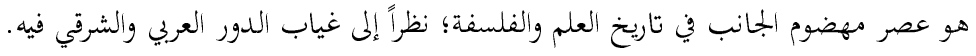

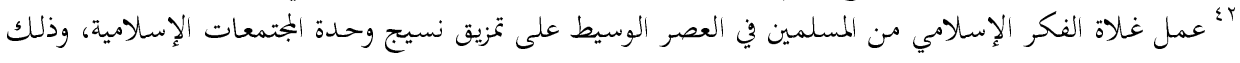

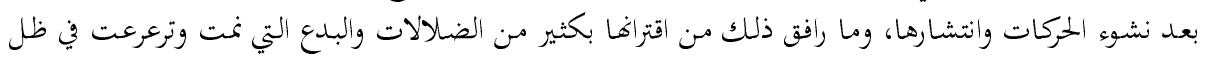

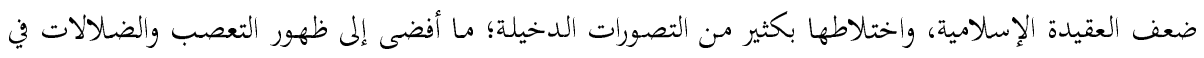

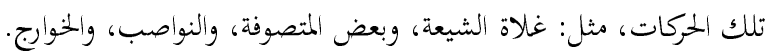

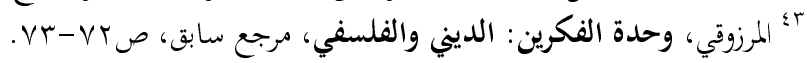




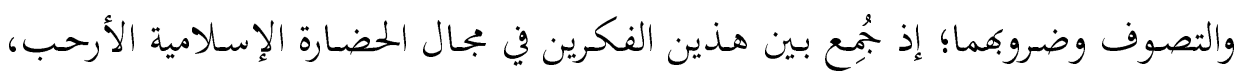

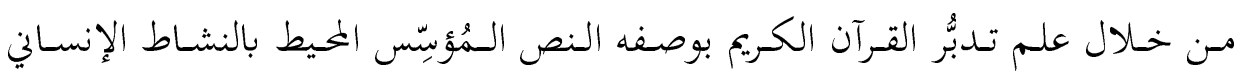
كله. ؛ «

لقد أجلى المرزوقي المنطق الداخلي الذي حكم الفكر العربي الإسلامي، وبيَّن فضله

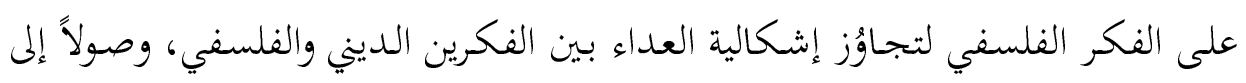

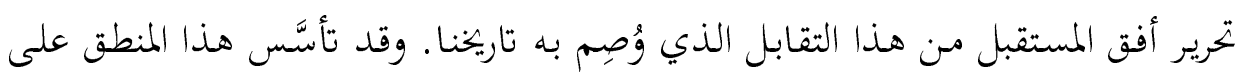
حقيقة أن هذين الفكرين متحدان في الجوهر بعيداً عن مغالاة الفكر الفلسفي، وتسطيح

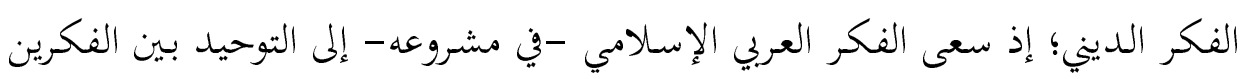
منذ صياغته في صورته النسقية وأصنافه المتعددة.

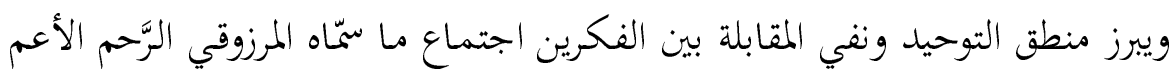

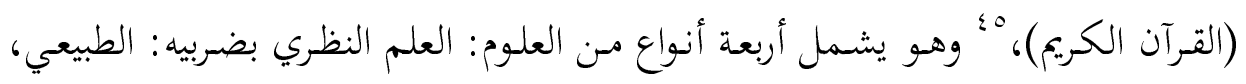

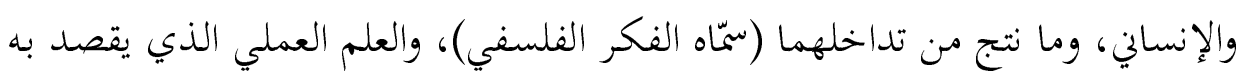

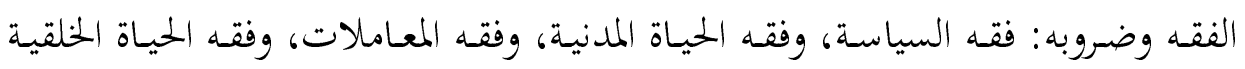

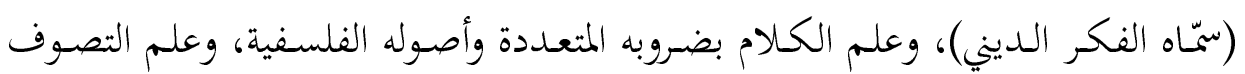

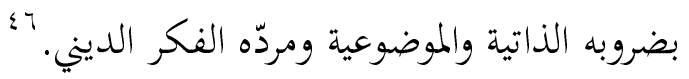

و تأسيساً على ذلك، فيان التحليل التاريخي للفكرين الـديني والفلسفي يُنبِتِ أهما

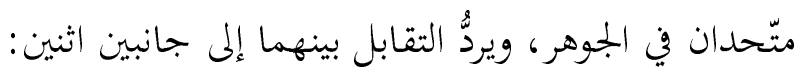
أ. جانب معرفي: يظهر في الغلو الذي يمارسه مَن يأخذها من جانب معرفي واحد؛ إمّا طبيعي، وإمّا شريعي، مُتنكِِراً للمعرفة الإنسانية بعمومها. ب. جانب توظيفي: يتمثَّل في توظيف كلٍ من الدين والفلسفة لغير ما جاء لأجله؛ ما حرفهما عن المسار والوجهة الأصيلة لكلِّ منهما.

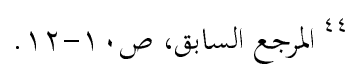

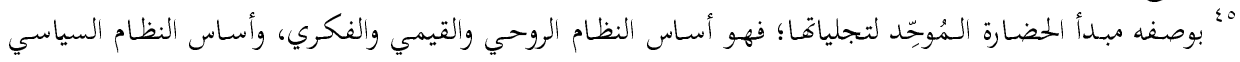

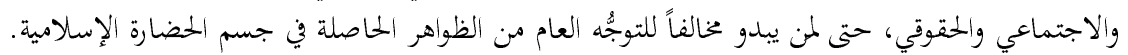

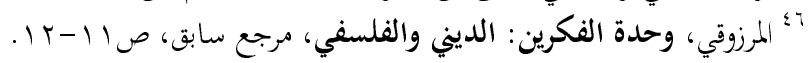




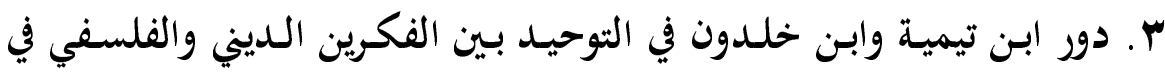

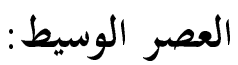

إن الصياغة النسقية للمشروع التوحيدي بين هذين الفكرين اكتملت بنقد جذاند بندي

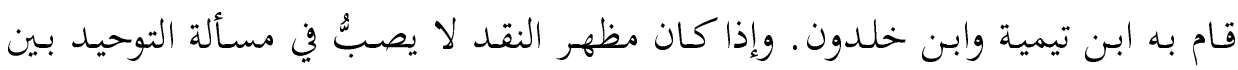

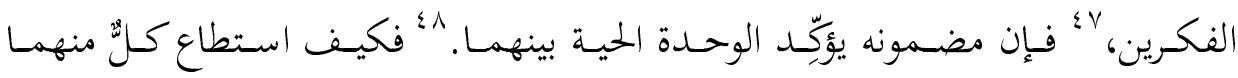

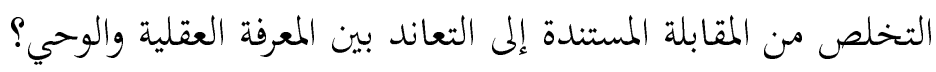

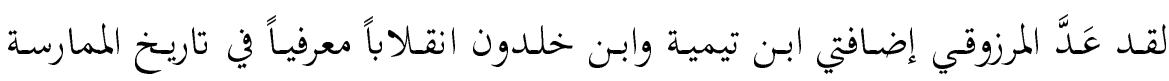

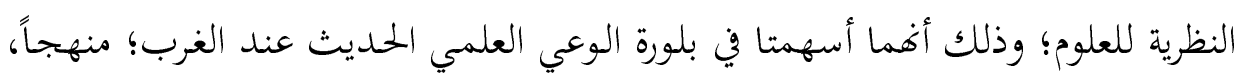

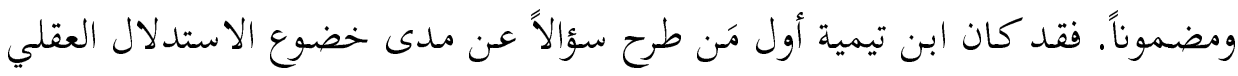

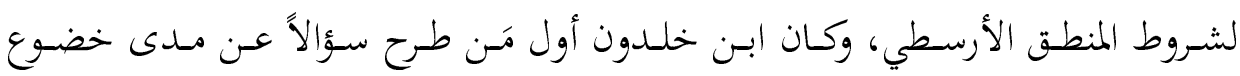

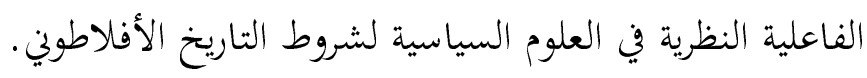

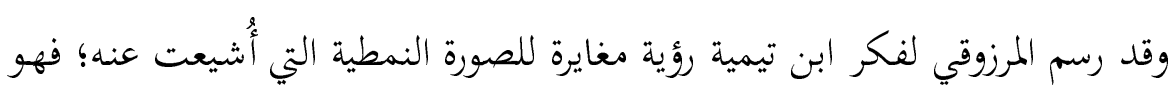

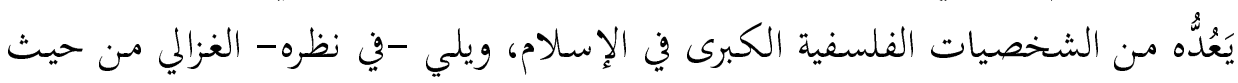

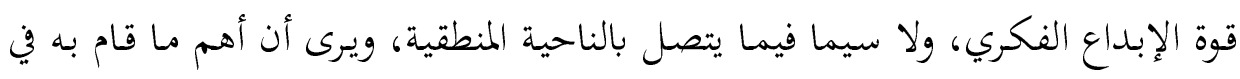

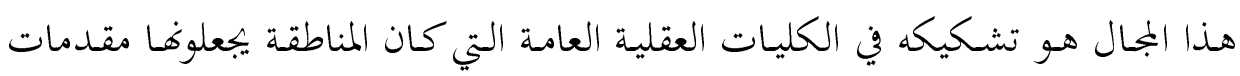

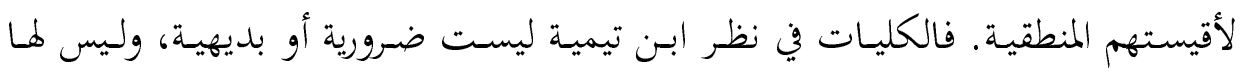

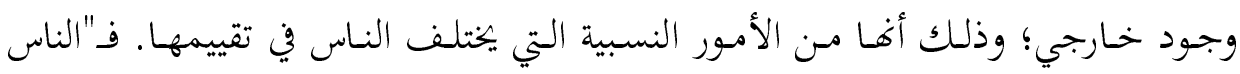

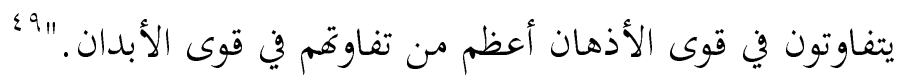

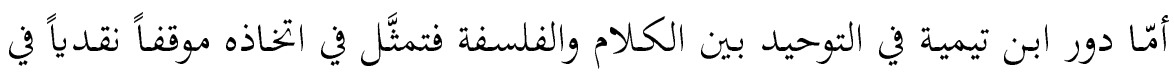

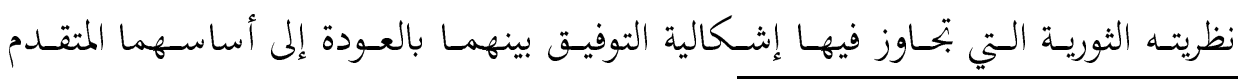

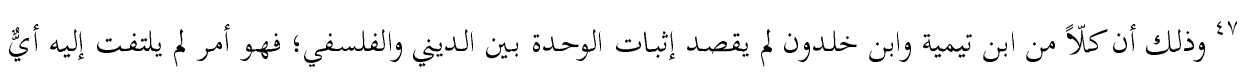

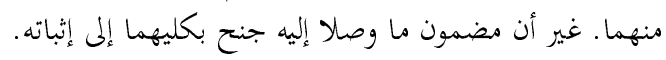
"اك لمرزوقي، أبو يعرب. إصلاح العقل في الفلسفة العربية: من واقعية أرسطو وأفلاطون إلى السمية ابن تيمية وابن

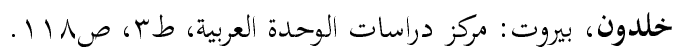

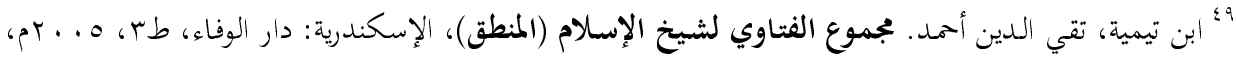
$.0 V \rho 69$ 


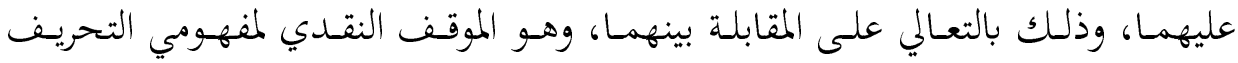

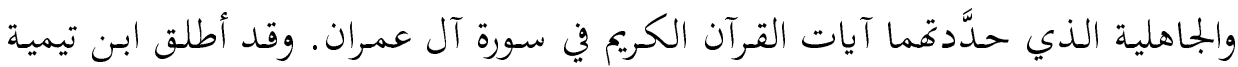
على هـا الموقف النقدي اسم منهج تصحيح المعقول وتصـريح المنقول (يُسمّى مـنهج المهرج

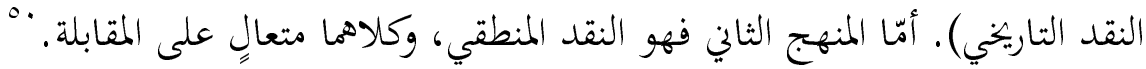
لقد استأنف ابن تيمية النقد على قاعدة أوسع تستند إلى تخليص ما بعد الطبيعة من

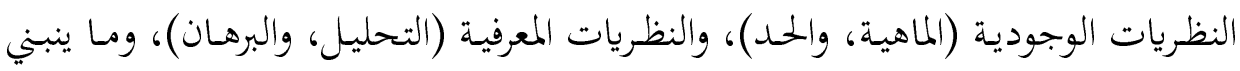

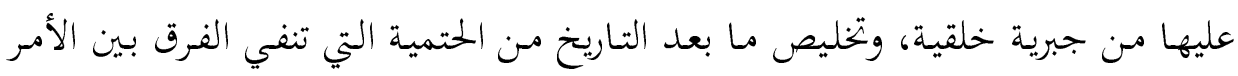

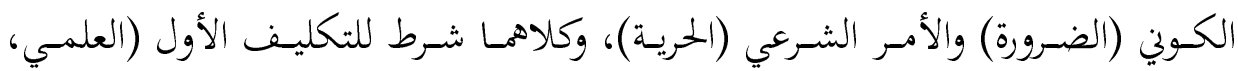

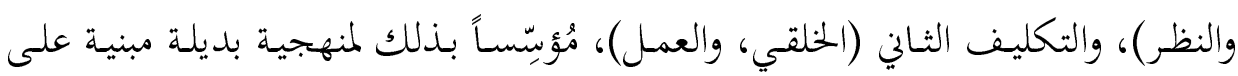
صريح المعقول (تخلو من الضمنيات)، وصحيح المنقول (صادقة، وحقيقية). وفي المقابل، فقد أضاف ابن خلدون إلى محاولة ابن تيمية تأسيساً نسقياً للمنهجية التي تُحرِّر العقل الإنساني من وطأة العائق الميتافيزيقي الذي يحول فئل دون فهم وظيفة الثقافة

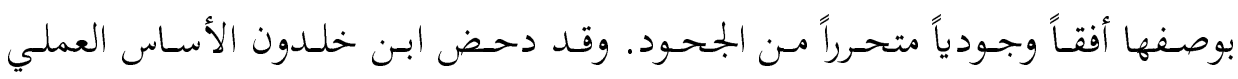

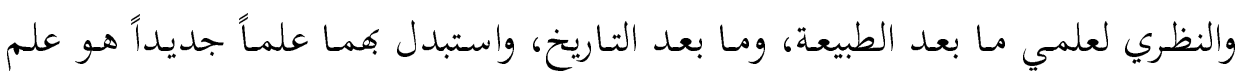

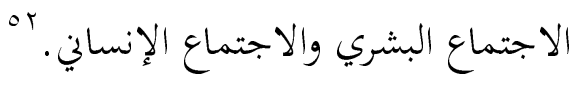

ويرى المرزوقي أن ابـن خلـدون عمـد إلى إلغـاء المقابلة بـين الطبيعي والشـريعي مـن

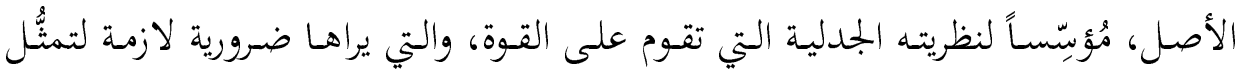

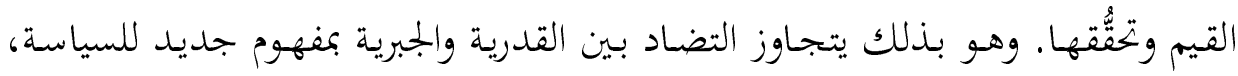

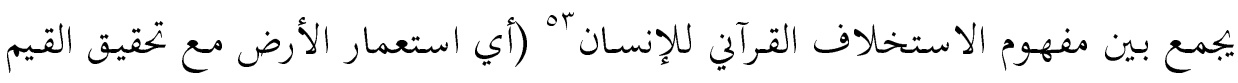

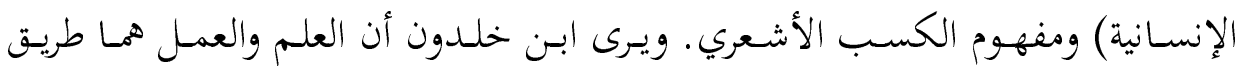

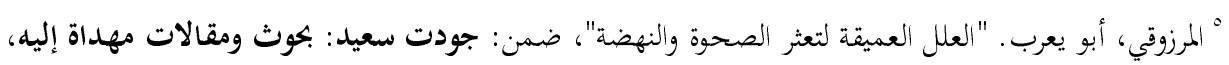

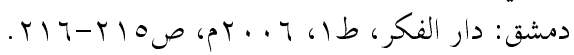

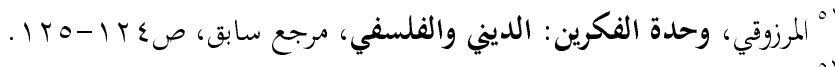

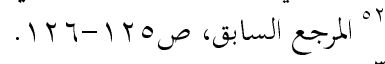

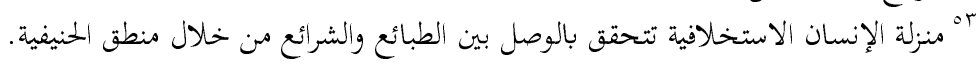


التحقيق الفعلي للسيادة البشرية، وأهما الدلالة العينية لخلافة الإنسان على الأرض من

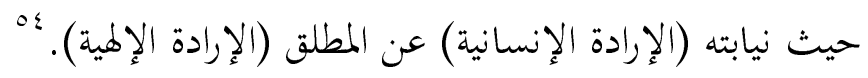

و تأسيساً على ذلك، فإن غاية كلِّ منهما في التحرير تصبُُّ في فكرة التوحيد بين الشريعي والطبيعي؛ إذ تتمثَّل غاية ابن تيمية في تحرير الإنسان من فئ عبادة الطبيعة، وذلك

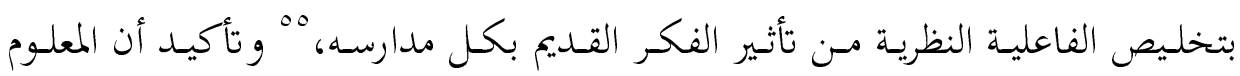

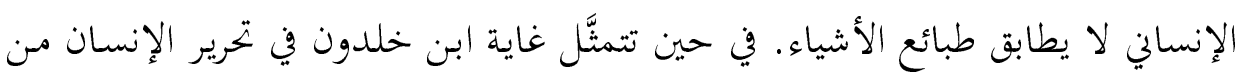

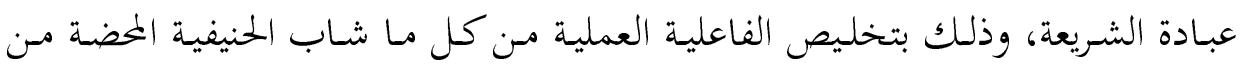

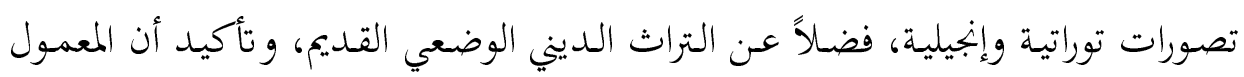
الإنساني -وهو العمل الإنساني- لا يطابق قيم الأشياء.

ع. نقــد المرزوقي التجربـة الجرمانيـة، ودوره في التوحيـد بــن الفكــين الـديني

والفلسفي:

سعى المرزوقي إلى بحاؤز الإشكالات الفلسفية والدينية التي حدثت على مرِّ التاريخ

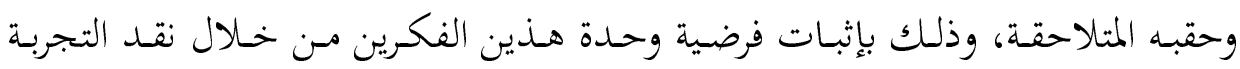

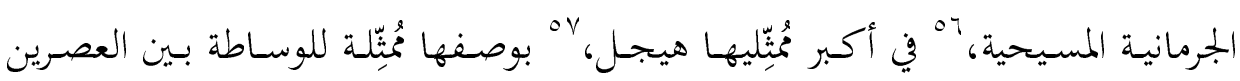

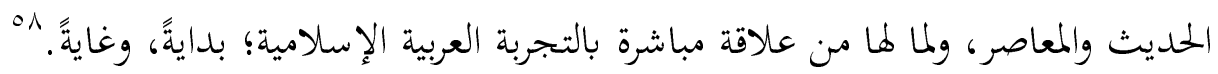

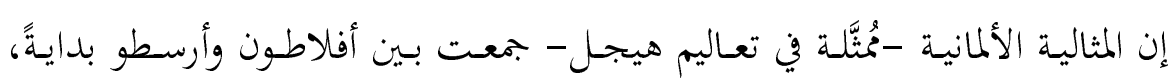

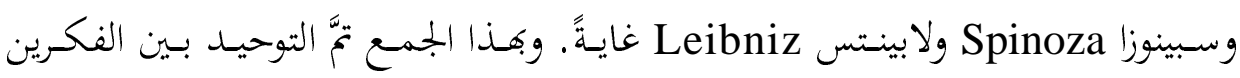

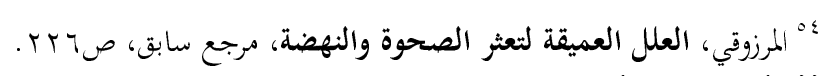

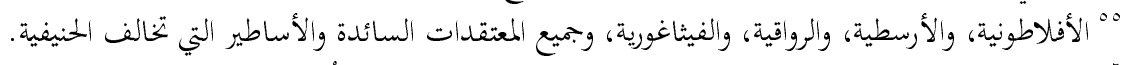

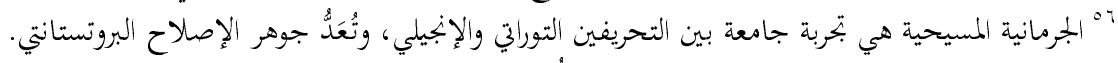

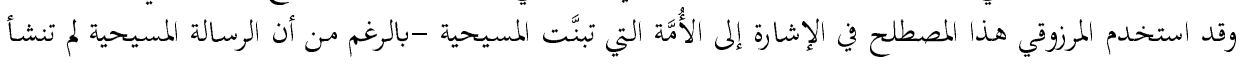

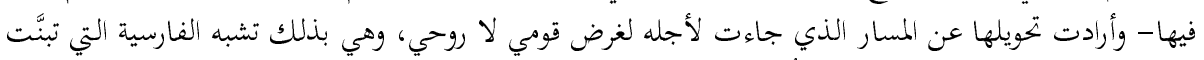

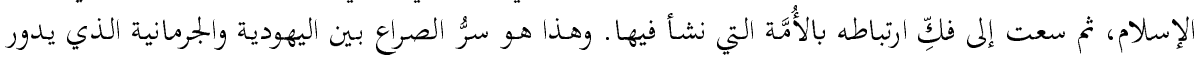

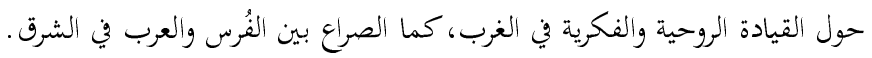
م أبوصفه أحد أهم مؤسسي الفلسفة المثالية الألمانية.

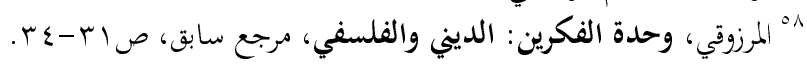


الفلسفي والديني توحيداً جحودياً، وذلك بإطلاق قوانين الطبيعة وجعلها مطلقة الضرورة،

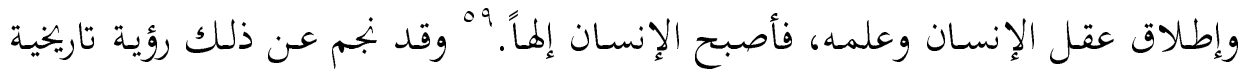
للقضاء والقدر تُمثِّل -بحسب المرزوقي - مبداً لتوثين التاريخ الإنساني.

لقد نقد المرزوقي تصور هيجل من حيث جعله الروح الكلية مُتعِينة في العَرضي من

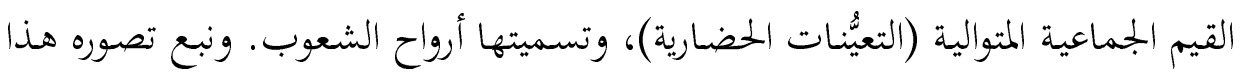

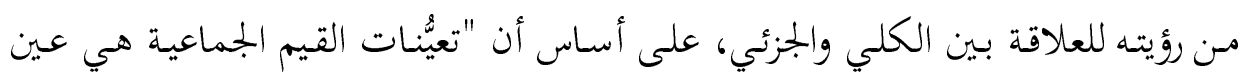

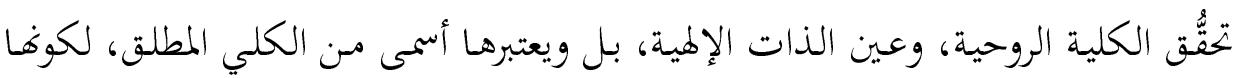

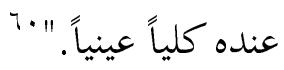

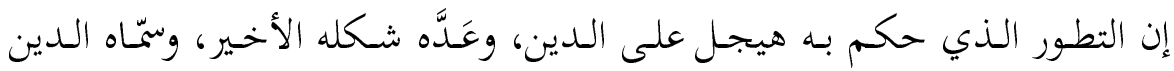

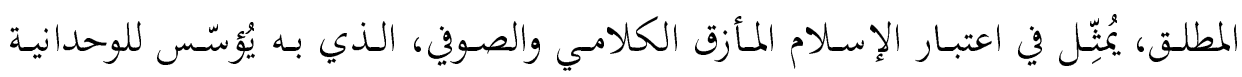
الروحية التي تهيمن على كل الحضارات، والتي تتحقَّق بها العولمة المسيطرة، ويتحلَّد أفقها

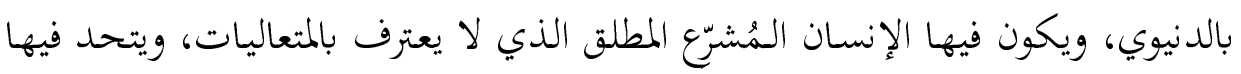

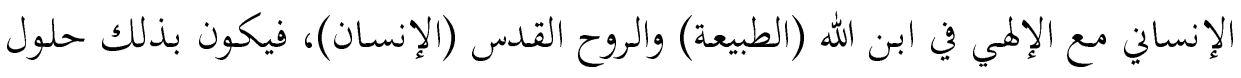
الإله في الإنسان. الإن الإن

وقد تمخَّض عن هذا النقد أمران: أولمما أن بؤرة الخلاف الظاهر بين الفكر الديني والفكر الفلسفي تصبُّ في ضروب القيم، من حيث صلتها بالوجود. وهذا يعود في أصله

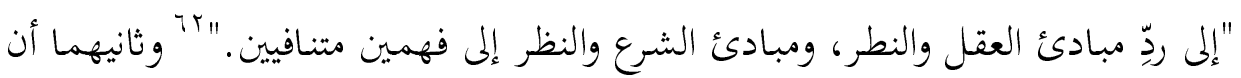

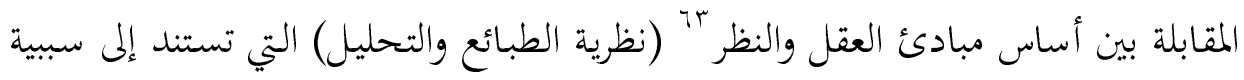

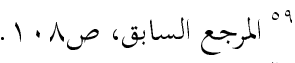

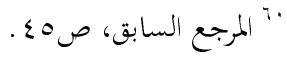

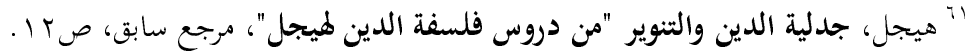

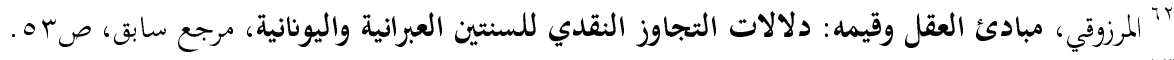

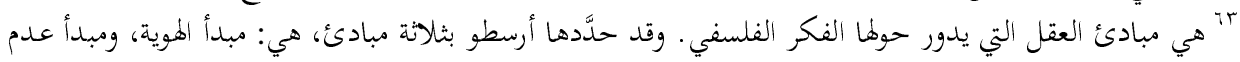

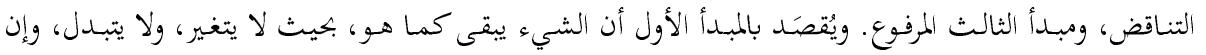

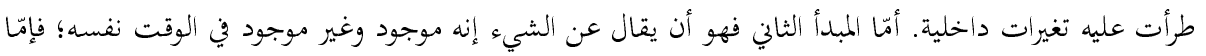

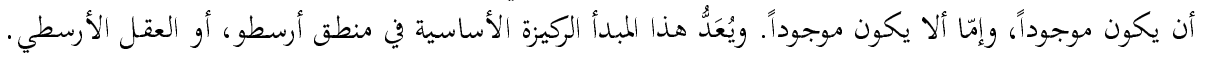

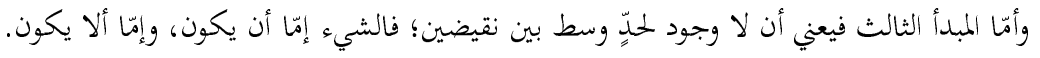


الضرورة الطبيعية، وأساس مبادئ الشرع والعمل عَ (نظرية الشرائع والتأويل) التي تستند إلى سبية الحرية الخلقية؛ أسَّست لفهم فلسفي جحودي، وفهم ديني جحودي.

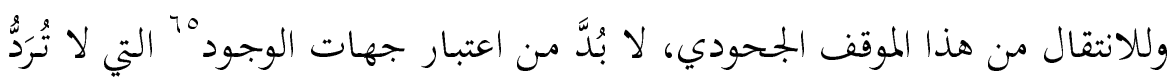

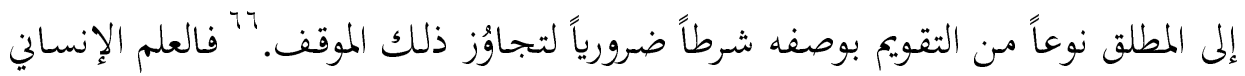

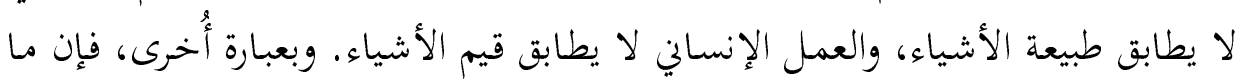

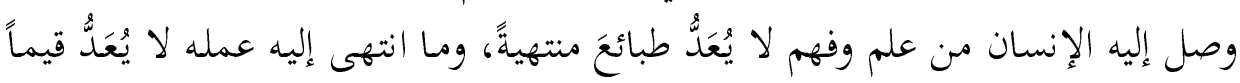

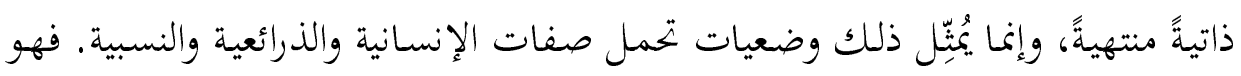

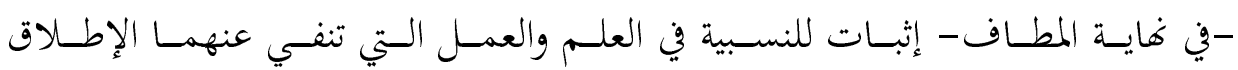
والحلولية.

\section{رابعاً: نظرية المرزوقي في مبادئ العقل والنظر، ومبادئ الثرع والعمل}

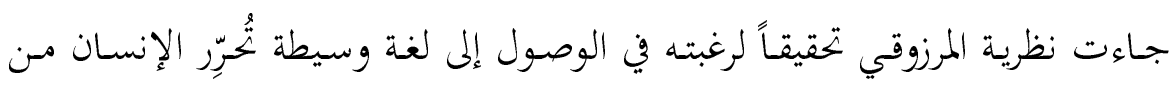

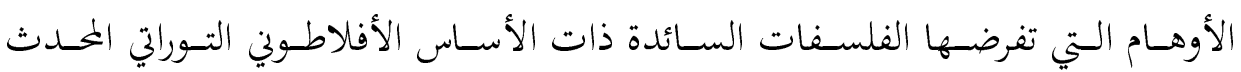
الجرماني، وبحلية الإشكالات الفلسفية والدينية التي يدور حوها الحنلاف بين الحضارة الحفارة التي

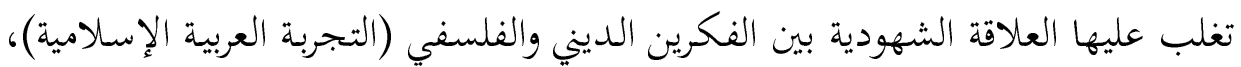

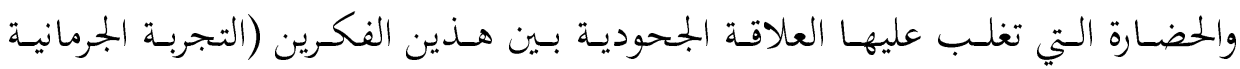
المسيحية).

وقد دعا المرزوقي في نظريته إلى صياغة تتجاوز التنافي بين الوضعيتين الثقافيتين، لحل

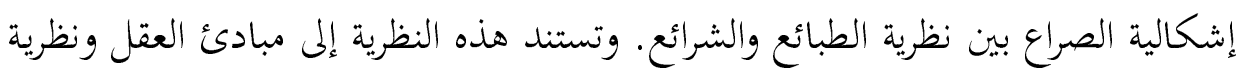

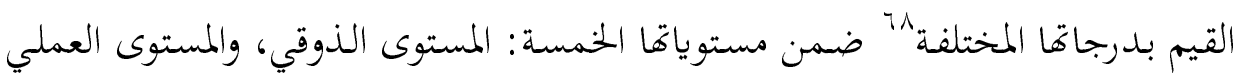
؛" مبادئ الشرع الثلاثة التي يدور حولها الفكر الديني، هي: الخلقة أو الهوية الموضوعة للوجود، والترجيح، والتحقيق للمعبرفة.

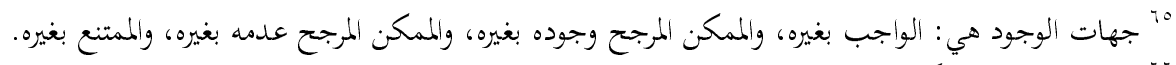

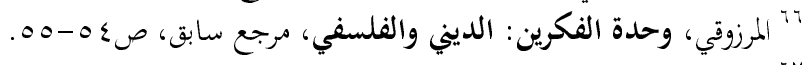

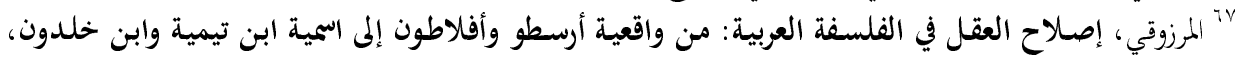

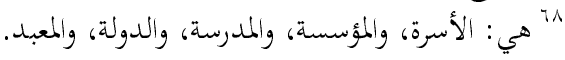


بالمعنى الخلقـي، والمستوى المعـري، والمستوى العملمي بالمعنى التشـيعي، والوجـودي في

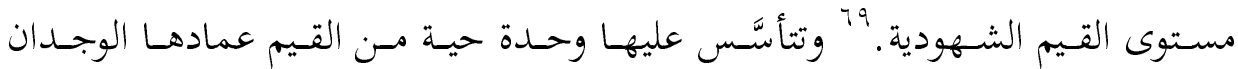

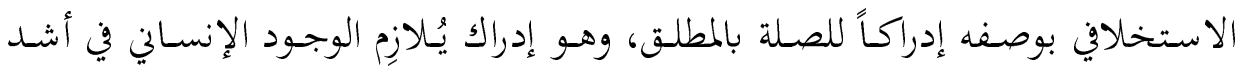

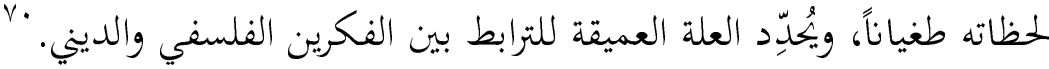
ومن الجمير بالذكر أن القانون الذي يربط بين مستويات التقويم الخمسة (الذوقي،

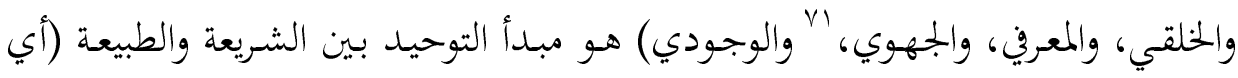

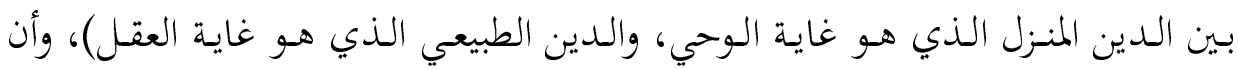

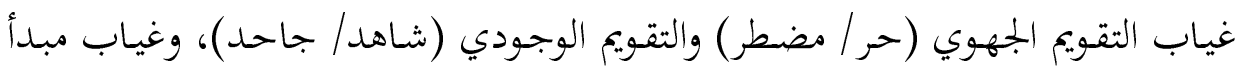
الترجيح (القدر) ومبدأ التحقيق (القضاء) في سلَّم المبادئ، هو أساس المقابلة التوثينية بين الفكر الديني والفكر الفلسفي.

ويُعَُّ المستوى المعرفي الثالث وسطاً بين المستويين الأولين والمستويين الأخيرين، وهو يكتسب أهميته مـن تحديـد الترابط بـين طبائع القيم، فيصل الغـايات التي يحملها الفـرد بالوسائل التي يسير بها المجتمع، فتحررالأولى من إطلاق المثال، وتحرر الثانية من إطلاق الواقـع. فالمعرفـة، ومنهـا الجلانـب الموضـوعي، تنقـل القـيم مسن بُعْدها الـذاتي إلى بُعْدها الموضوعي، وهي الأساس الذي يُبنى عليه الاجتهاد الإجماعي الذي يكون دائماً مشدوداً

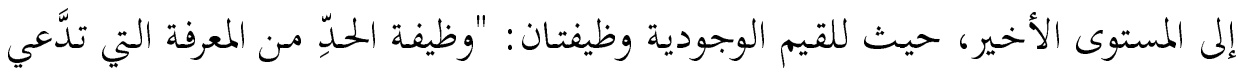
الإحاطة لتذكير الإنسان بمحدوديته، ووظيفة تحرير إدراك التعالي من كل حصر في في المعرفة المحدودة لتذكير الإنسان بربه." Vr"

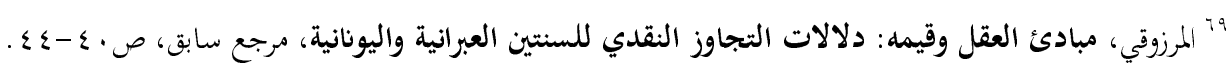

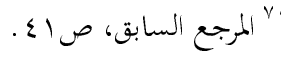

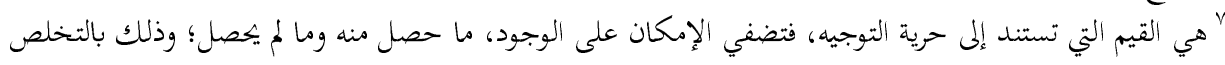

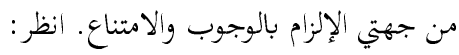

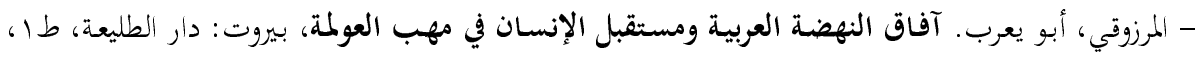

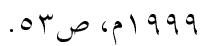
بr

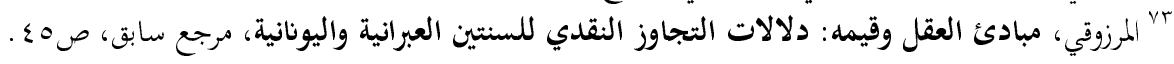


ويرى المرزوقي أن مبادئ العقل والنظر ومبادئ الشرع والعمل شرط لكل تقويم، من

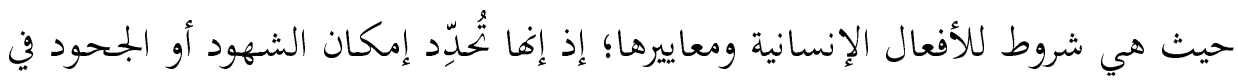

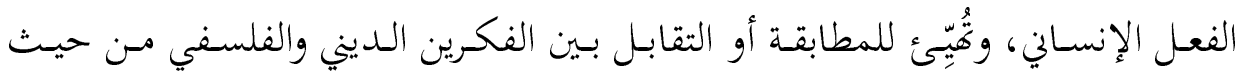

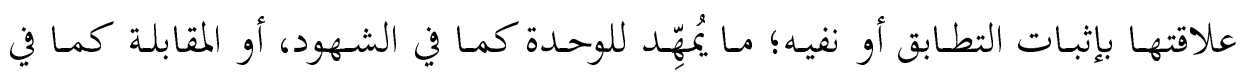

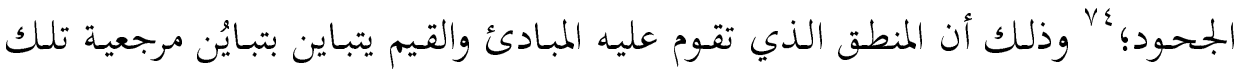

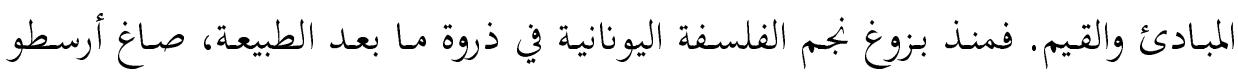

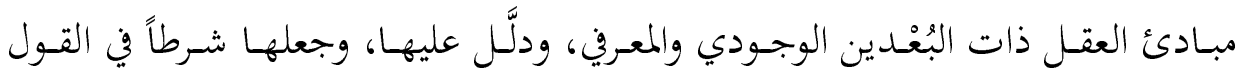

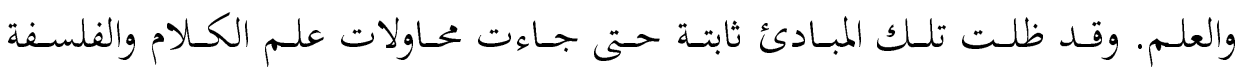
الإسلامية، فزعزعتها باندماجها فيها، وبلغت ذروتها في فلسفة ابن سينا ورد الغزالي عليها بوجه8ا النقدي.

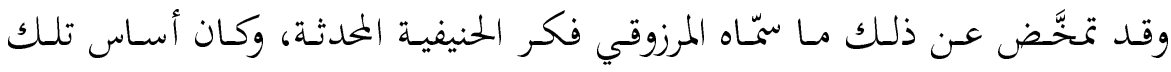
المحاولات هو نفي التقابل بين ما يمكن تسميته نظرية الشرائع والخلقات (جمع خلقي بمعنى

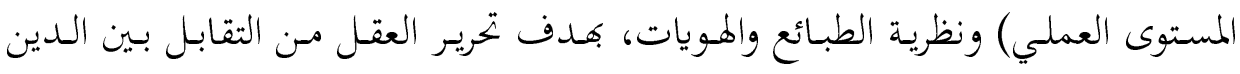

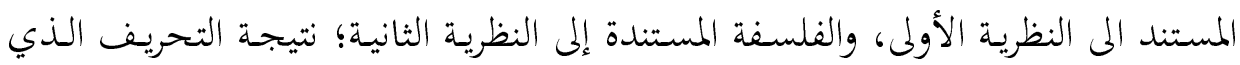
طرأ على كليهما.

وعلى هذا، فإن المرزوقي لم يسند العمل والنظر إلى ختم الإطلاق الميتافيزيقي، بمعنى

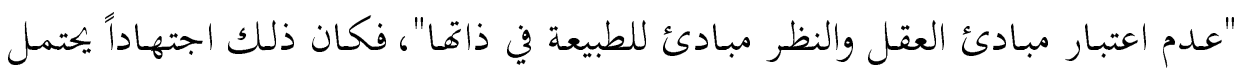

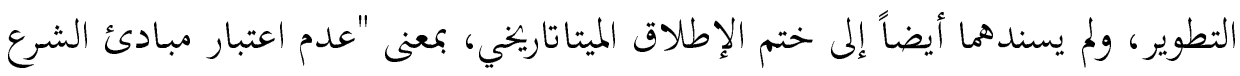

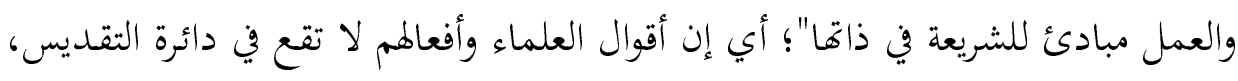
وهذا ينفي عنهما وهم الإطلاق.

إن اقتصارنا على المبادئ الثلاثة الأولى التي سادت في مرحلة ما قبل الثورة عليها في

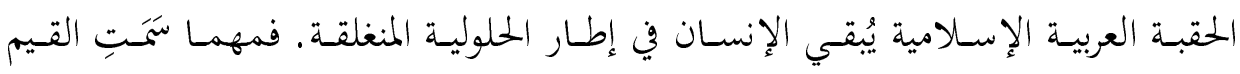

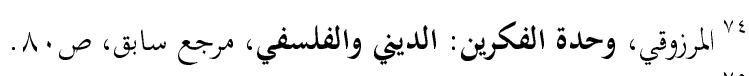

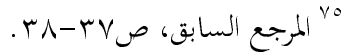

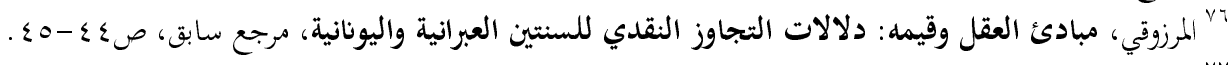

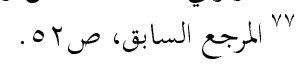


الإنسانية الحضارية خُلقياً فإنها تبقى دون المطلق، وهي في صبو دائم إلى الشهود، ومهما

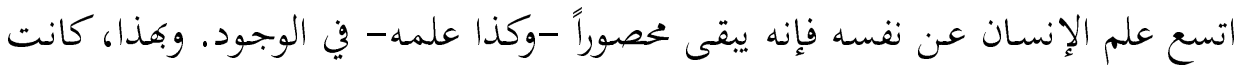

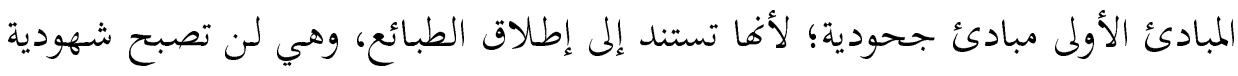

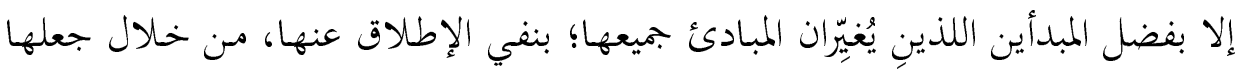

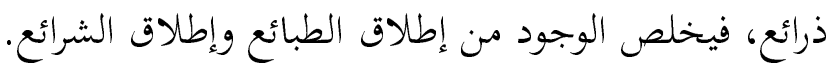

\section{خامساً: دور الحنيفية المحدثة في التوحيد بين الفكرين الديني والفلسفي}

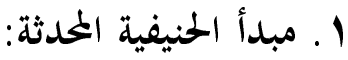

يبني هذا المبدأ استدلالاته على اعتبار أن الطبيعة والتاريخ آيتان دالتان على شروط

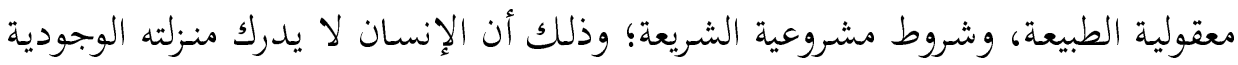

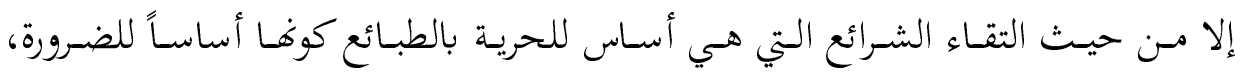

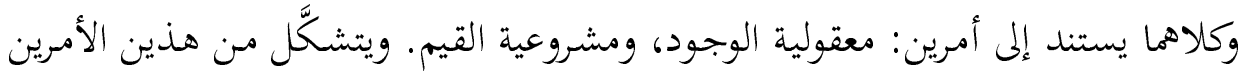

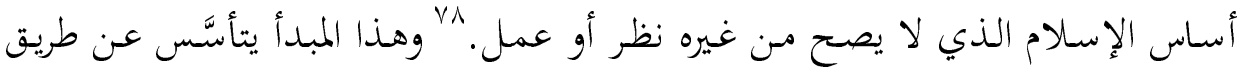

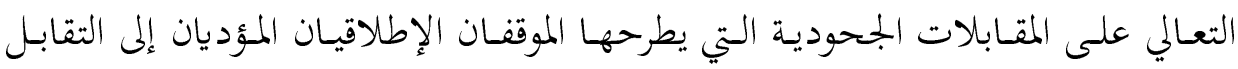

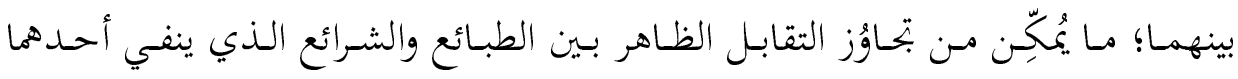
الآخر.

\section{وقد تميَّز موقف الحنيفية بمسألثين وَفقاً للمرزوقي:}

أ. الاعتقاد الصريح بالتوحيد بين الدين الطبيعي الأسمى (الذي لا يستثني الشرائع)

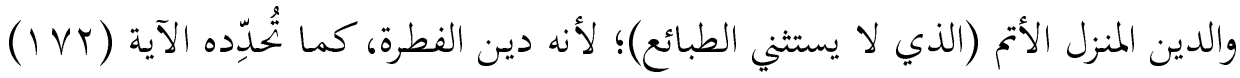

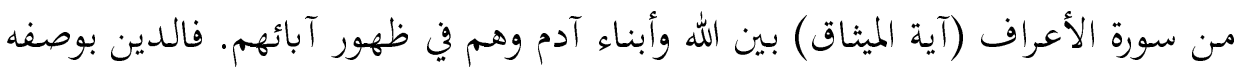

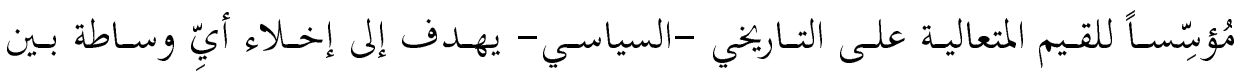

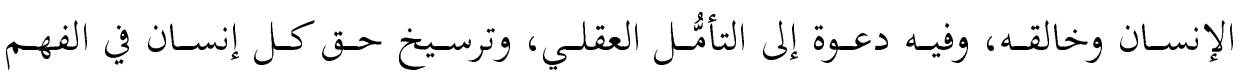

$$
\text { والإدراك. }
$$

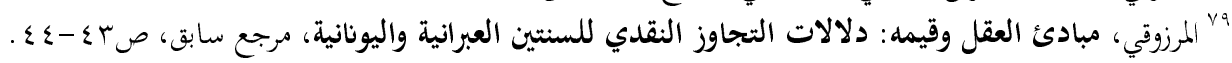


ب. الاعتقاد الصريح بختم الوحي، أو فاية التنزيل؛ نظراً إلى اتحاد التاريخي والطبيعي

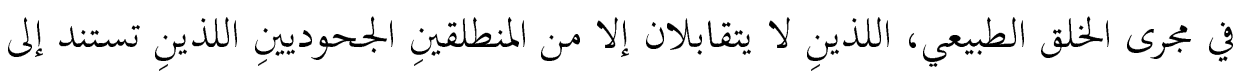

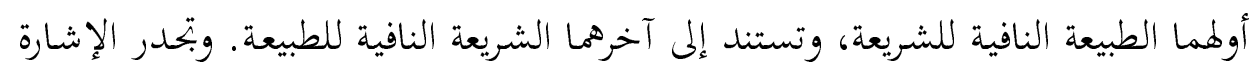
إلى أن هذا الاعتقاد ناتج من الاعتقاد الأول. إن ختم الوحي المصحوب بنفي السلطان الروحي المعصوم يمكن أن يُستعاض عنه بسلطان الاجتهاد الإجماعي المستند إلى الاستخلاف العام، الذي يصبح فيه كل إنسان

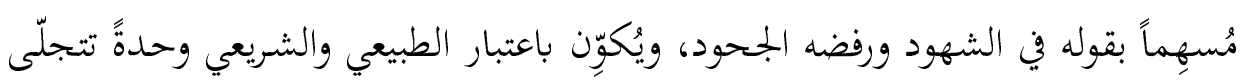

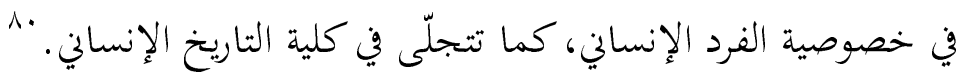

ץ. المبادئ التي يقوم عليها عمل العقل والنظر لغـايات الوحسدة بين الفكرين

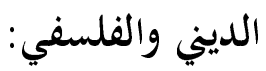
إن تمكُُ فكر الحنيفية المحلثة من نقد التجربة الفلسفية أفضى إلى اكتشاف مبدأين آخرين في الحقبـة العربية الإسـلامية يُكمالان مبـادئ أرسطو، هما: مبدأ الترجيح، ومبـدأ

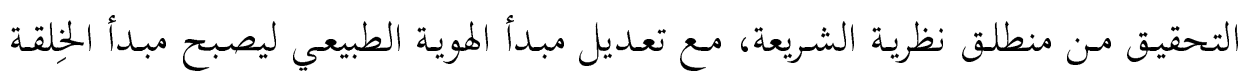

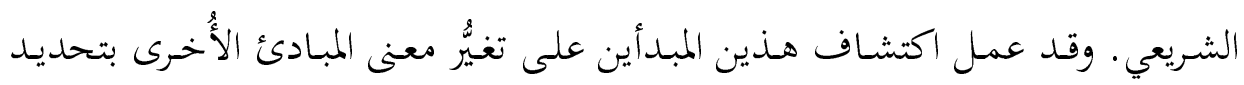
شروط وجودها؛ ما ساعد على تجاوُز منبع إشكالية التقابل بين نوعي المبادى (العقلية-

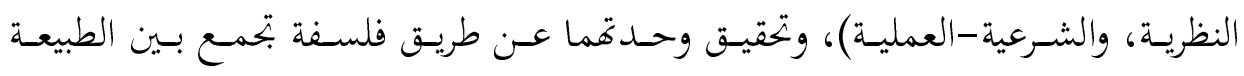

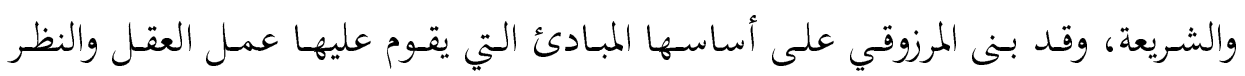

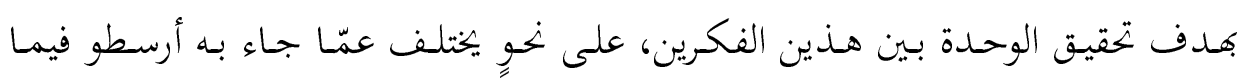

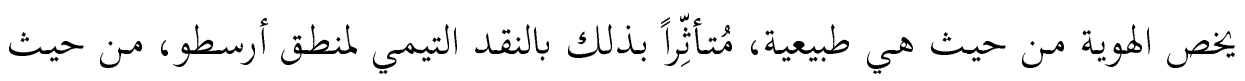

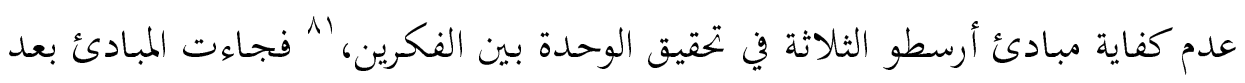

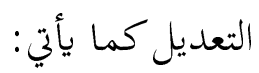

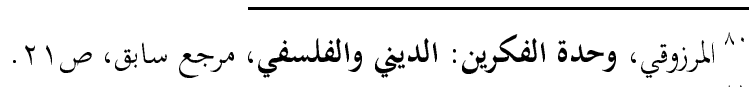

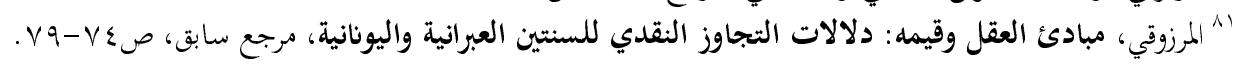


أ. مبـدأ المويسة المعسدل: رأى اليونان، ومسنهم أرسطو، أن للهويـة جـوهراً صسورياً في

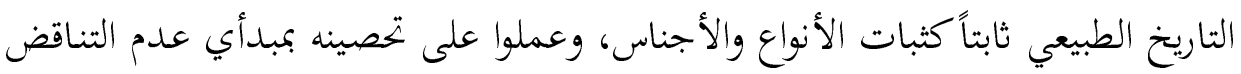

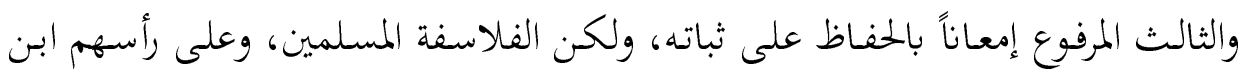
سينا، ثم الغزالي الذي تبعه على وجه الخصوص، رأوا في الهوية "خلقة حكمية متغيِّة تغيير

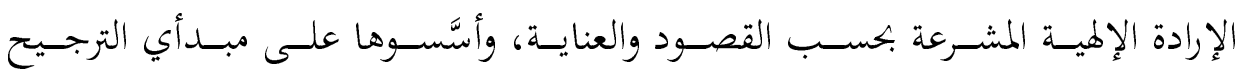
والتحقيق. الإده الإد"

وأصبح مبدأ الهوية بعد التعديل يُعَفَ باسم مبدأ المِلقِة الشريعي، بناءً على أن كون

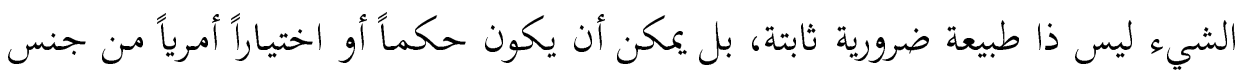

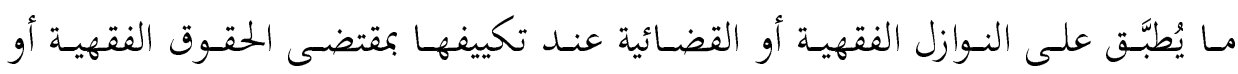
القضائية.

وهو منبع القيم الجمالية، وصورة للوحدة الحية، يتعدَّد بتعلُّد الصفات، ويتغيَّر وَفق

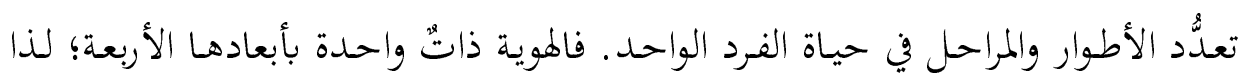
فهي فاعلة ومنفعلة تتضمن علاقة الفعل بابتاه الفاعلية والانفعالية. ب. مبدأ عدم التناقض: أصبح هذا المبدأ منبعاً للقيم الخلقية بمفهومه المعدّل، وهو

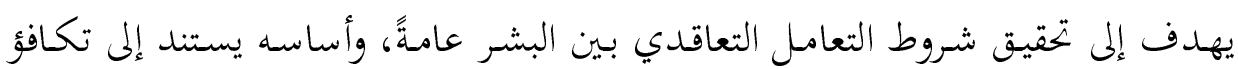

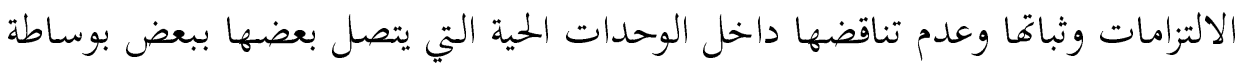

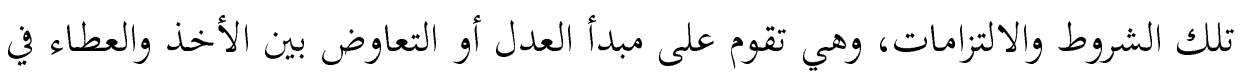
المعاملات والعبادات.

ت. مبدأ الثالث المرفوع: أصبح هذا المبدأ منبعاً للقيم المعرفية بمفهومهه المعدّل، وهو يهدف إلى تحقيق الفصل بين الآراء المتقابلة مسن حيث مطابقتها للمقياس المطلوب، وبه يُقاس الحكم الإجماعي لقضية ما، ولكن من دون زعمٍ للمطابقة المستغرقة التي من صفاتما

$$
\begin{aligned}
& \text { "المرجع السابق، ص77. }
\end{aligned}
$$

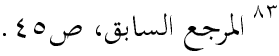

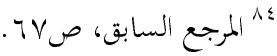


الثبات؛ كوها لا تتحقَّق إلا في العلم المحيط. وعلى هذا، فلا يمكسن للمعرفة أن تتقدَّم إذا

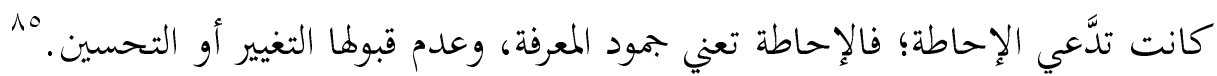
ث. مبدأ الترجيح: هو المبدأ المعدل لكل المبادئ السابقة، ومنه تنبع القيم الجهوية،

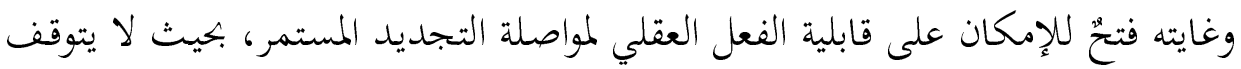

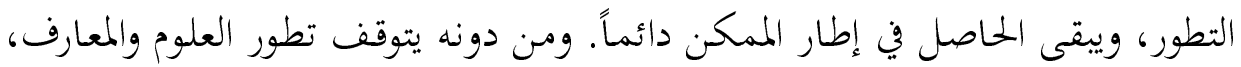
وبفضله لا تكون الموجودات طبائع ضرورية، وإنما شرائع اختيارية لا تحكمية. ومعنى الترجيح يأتي من الفعل "رجَّح"؛ أي: زاد، وقوّى، وجاوَز ، وهو على درجتين؛

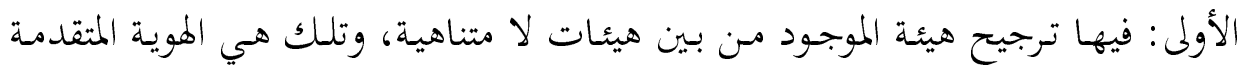

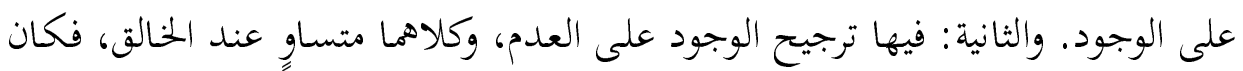
لزاماً وجود مرجح، هو الإرادة الإلهية.

ج. مبـدأ التحقيـق: هـو المبــأ المعـدّل للمبـادئ الثلاثـة الأولى، ومنـهـ تنبـع القـيم الوجودية، وهو أساس منزلة الاستخلاف الوجودية، وغايته التمييز بين الشهود والجحود؛

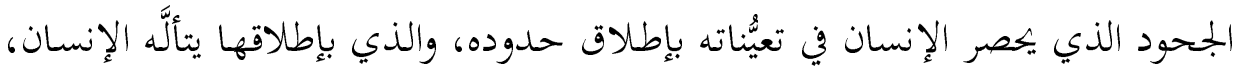

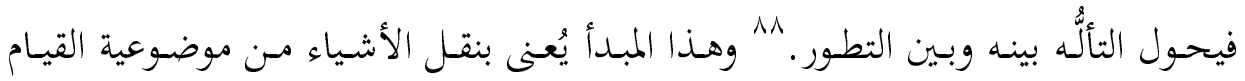
بالقصد إلى موضوعية القيام بالذات، وهو ضروري لازم لترجيح تحقيق الإنيّة، ويُصطلَح على تسميته باسم القضاء. 19

r. أساس التوحيد بين الدين والفلسفة: يقوم التوحيد بين الدين والفلسفة على أساسين اثنين: أ. اعتبـار معطيـات الوجود الشـريعية قائمـة الذات، مثلهـا مثل المعطيـات الطبيعيـة؛

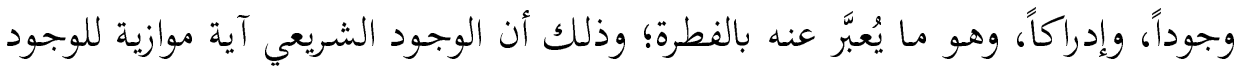

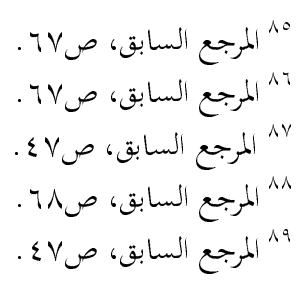


الطبيعي. فالفصل بين الفكر الديني (علوم الشريعة) والفكر الفلسفي (علوم الإنسان) لم

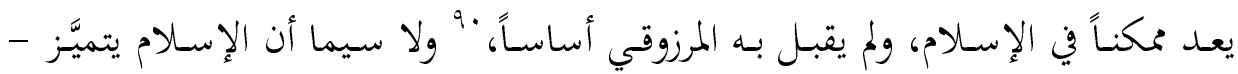

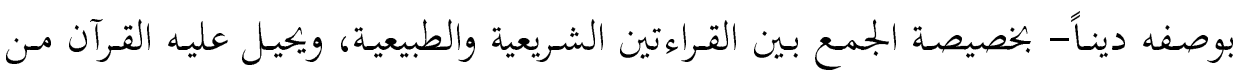

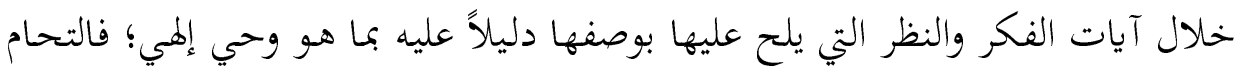

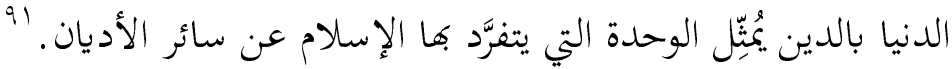

ب. اعتبار الوحي أمراً جامعاً بين الدين الطبيعي (العقل) والدين الشريعي (النقل)؛

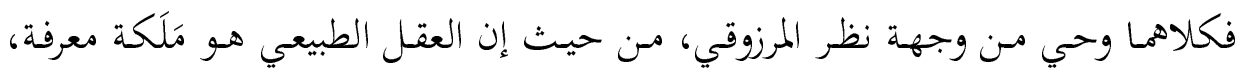

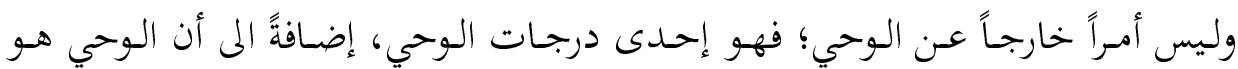

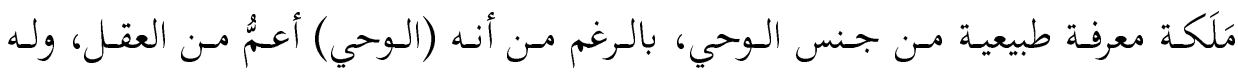

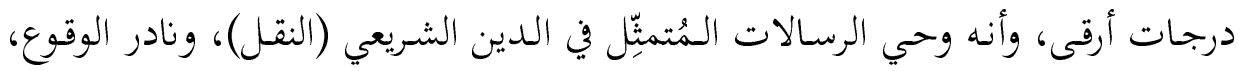
وقد تيَّ فخحُتِم.

\section{ع. رؤية المرزوقي للوحدة بين الديني والفلسفي:}

واجه المرزوقي التحريف الذي طرأ على كلا الفكرين من منطلق أن الدين والفلسفة

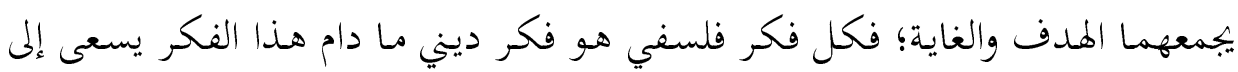

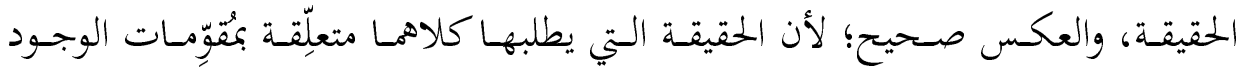

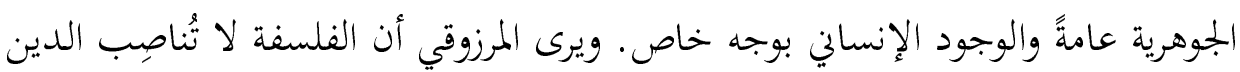

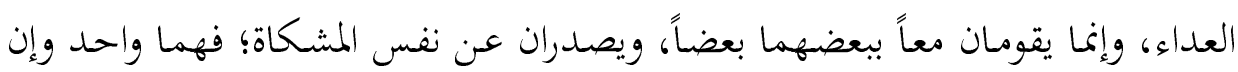

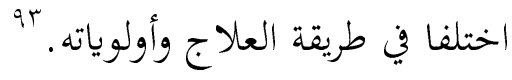

إن غاية الإحياء الذي جاء به الإسلام بوصفه رسالةً خاتمةً للوحي -مـن وجهة نظر

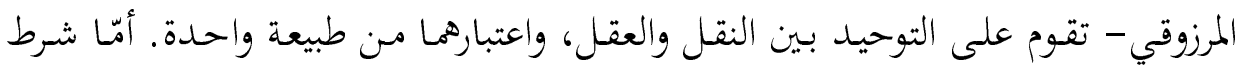

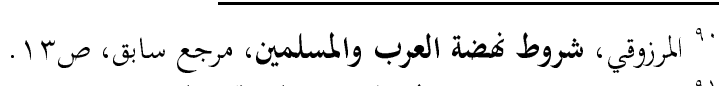

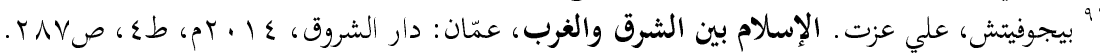

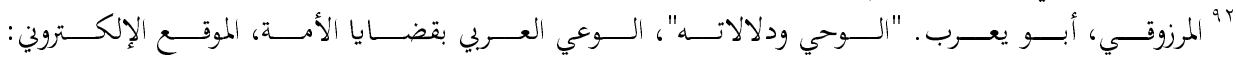
.https:/abouyaarebmarzouki.wordpress.com

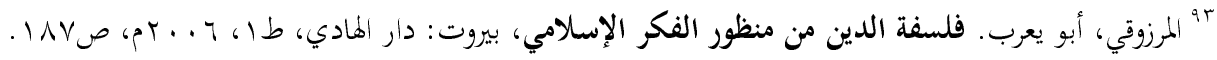




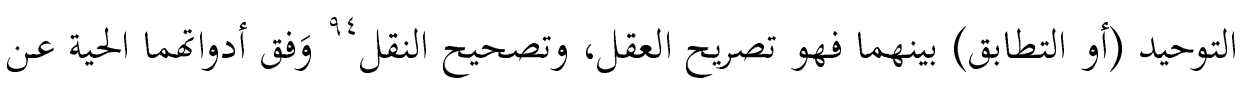
طريق الاجتهاد، وهو التواصي بالحق.

وفكرة التطابق مردُّها أن الفطرة، وهي الدين الطبيعي، متطابقة مع الدين المنزل من

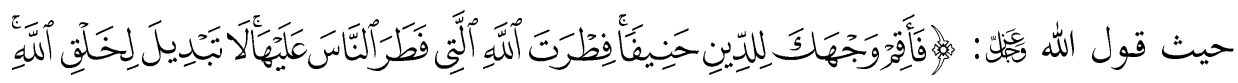

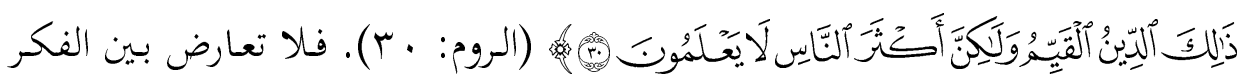
الفلسفي والفكـر الديني، مـن حيـث إن الفطرة مُهيَّأة لقبول التصسور الإنساني لـآيات الكونيـة في الكسون والطبيعة والنفس الإنسـانية، ومطابقتها بالآيات الشـرعية الـمُتمبثّلة في

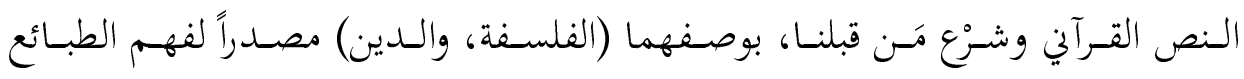
والشرائع؛ كلٌّ بطريقته وأدواته.

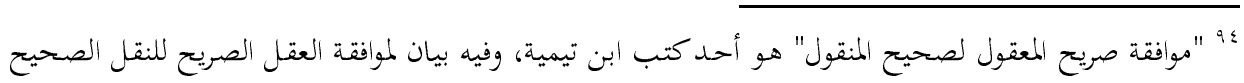

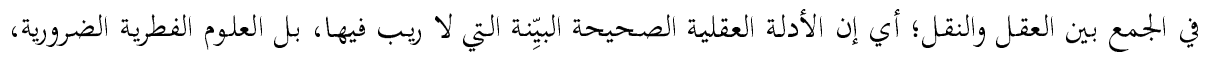

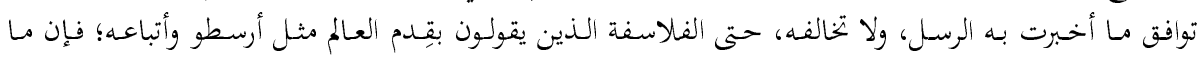

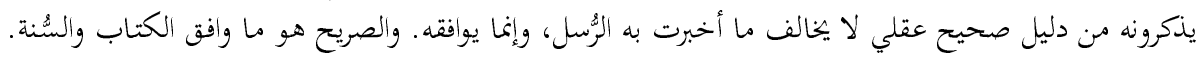

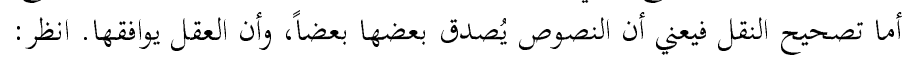

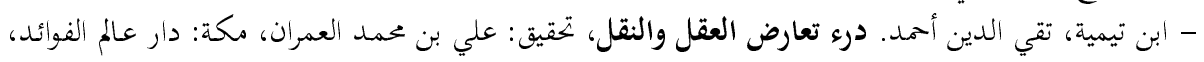

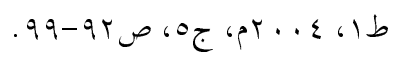

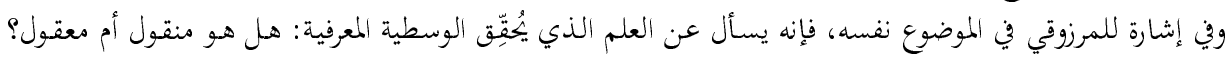

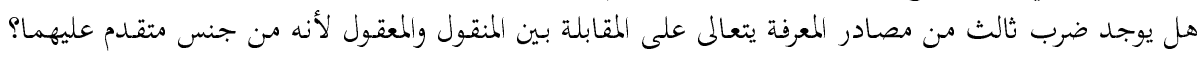

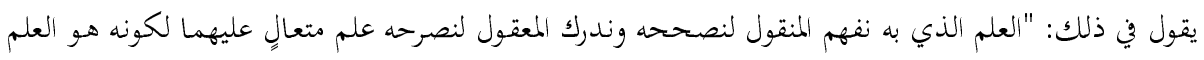

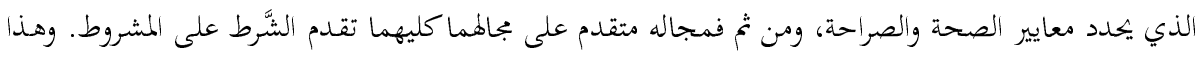

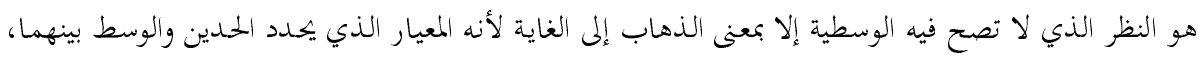

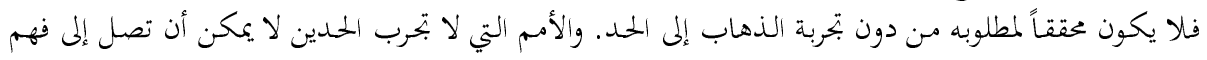

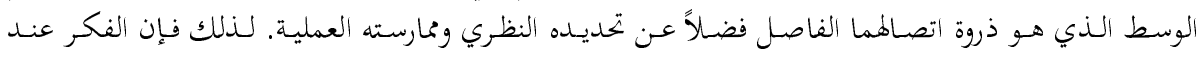

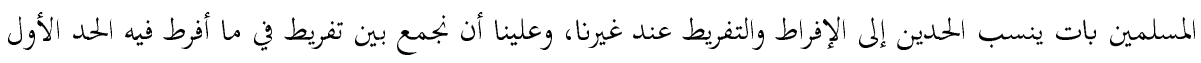

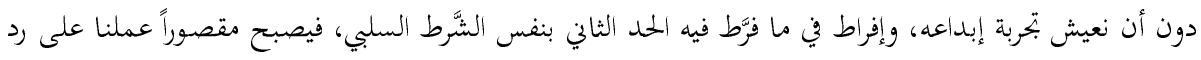

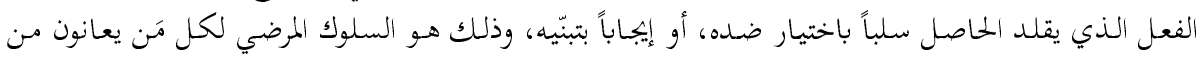
التبعية الروحية." انظر: الفعل الفيل الخاصل - المرزوقي، أبـو يعـربـ. "وسـطية العقلانيـة الإسـلامية: المسـألة الأولى"، الـوعي العـبـي بقضـايا الأمـة، الموقـع

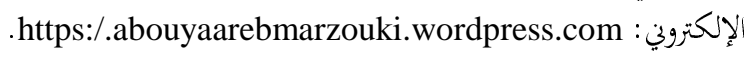

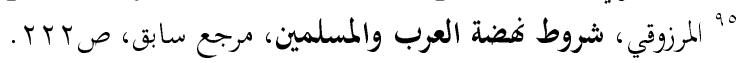


ففهم كلام الله وامتثاله يكون وَفق أمرين؛ الأول: دلائل آيات الله الكونية؛ أي فهمنا

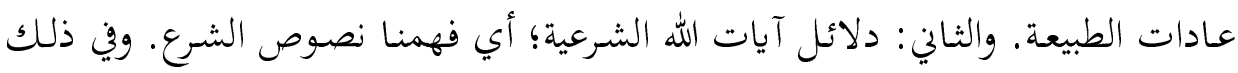

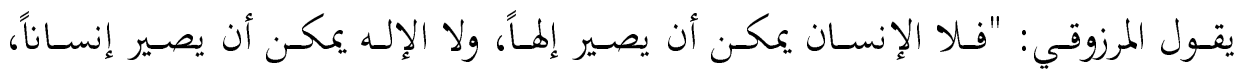

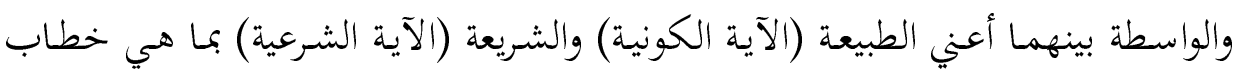

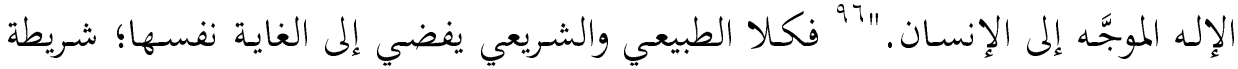

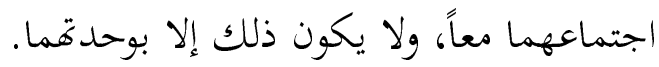

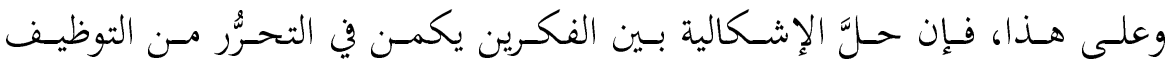
والجحود، وذلك بالجمع بين الدين الطبيعي والدين المنزل في دين الفطرة (الحنيفية المخضة)

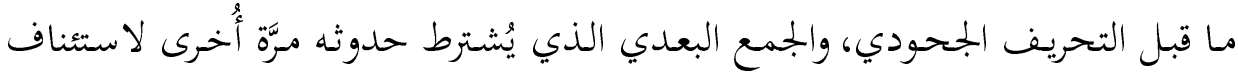

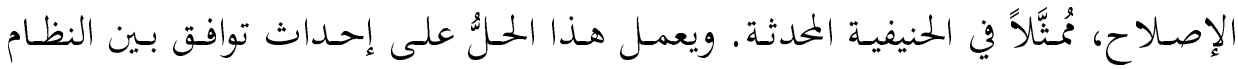

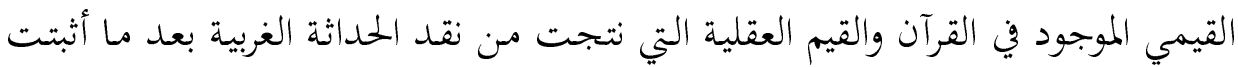

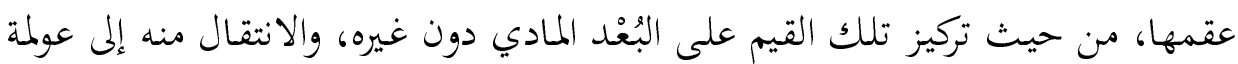

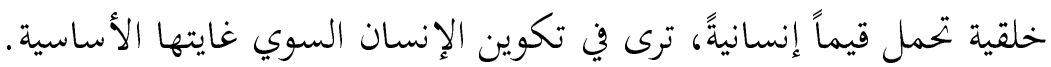

خاتمة:

تُعَدُُّ محاولة "أبو يعرب المرزوقي" واحسدة مس أبرز المحاولات -على مستوى الفكـر

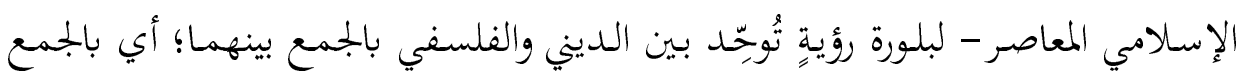

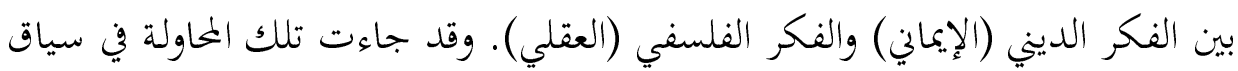

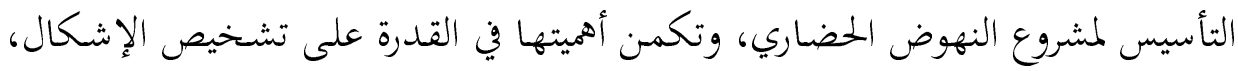

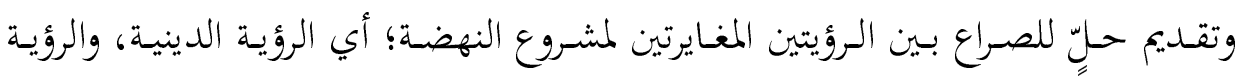
العلمانية.

وقد قامت هذه الرؤية على تصور تاريني بنيوي، مفاده أن تاريخ الإنسانية الفكري

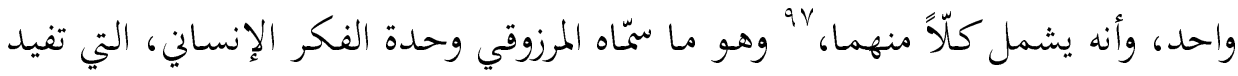

كج"9 الهجلة، إصلاح العقل في الفلسفة العربية: من الواقعية إلى الاسمية (قراءة في كتاب)، مرجع سابق.

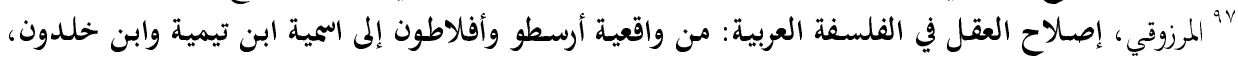


أن تاريسخ الإنسـانية الفكـري هـو تاريسخ واحـد بتركيبتهـ الفلسفية والدينيـة، وأن التحريـف الذي أصساب الفكرين الفلسفي والديني أعاق التوحيد بينهما. وقد ماتل تصوّر المرزوقي للتـاريخ تصوّره للدين الكلي، الذي يتطابق فيه الدين المنزل الخـاتم (الوحي) مـع الدين الطبيعي (العقلي)، وهو دين الفطرة، باعتبار أن التحريف الذي أصابهما هو الذي عاق عملية التوحيد بينهما.

لقد أكمل المرزوقي ما بدأه الفلاسفة المسلمون في العهد الوسيط (ابن سينا والغزالي بدايةً وابن تيمية وابن خلدون غايةً) من بحاؤز لما جاءت به الأفلاطونية المحدثة، وسمّى ما

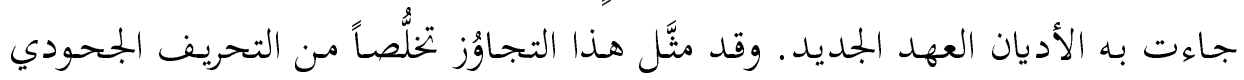
الذي أصاب الفكرين الديني والفلسفي في ذلك الوقت.

وجمع المرزوقي بذكاعٍ بين مُلهِمينِ لأكثر الحركات والأيديولوجيات تنافراً: اليسار مُمثَّاً

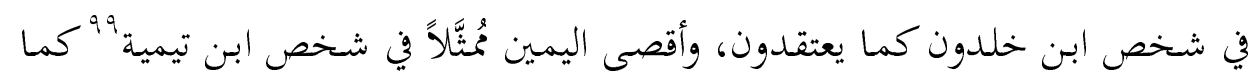
يعتقدون أيضاً، في محاولةٍ منه للتقريب بين النّخب المتبن المتارعة. وقد قدَّم عن طريق الدمج بين نموذجي ابن تيمية وابن خلدون تصوراً تاريخياً وبنيوياً لتاريخ الفكر الإنساين الموحَّد، لئه الذي عَدَّه "ثورة" في مسار تطور الفكر الإنساني، والذي جمع بين جنبيه أسس التنوير الديني والعقلي.

وقـد بتلَّت جوانسب الجـدة في مشـروع المرزوقي، في قدرتسه على تقـديم إضـافات في جوانب ثلاثة: مفهومية، ومنهجية، ومعرفية.

أمّا الجانب المفهومي فتمثَّل في قدرته على توليد المصطلحات المتعلِّقة بمشروعه، مثل مغهوم "الخلقة التشريعية"، وهو مبدأ قَصَدَ بـه المستوى العملي الذي يعني قابلية المبادى

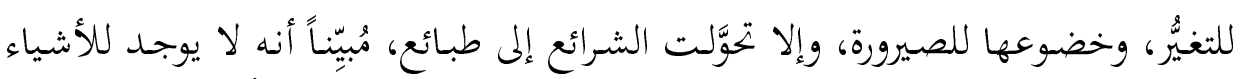

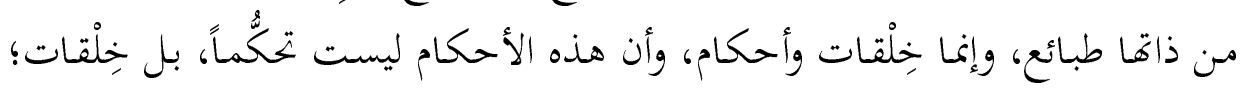
هو المرزوقي، أبو يعرب. "فكر ابن تيميـة الإصلاحي: أبعاده الفلسفية"، جع، الوعي العربي بقضايا الأمـة، الموقع الإلكتروين: المروفي ابو يعرب.

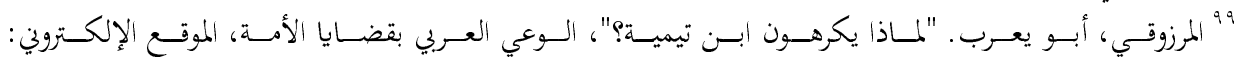
.http://www.alukah.net/translations/0/28620/\#ixzz4EnhW3p6g 
فهي في تطور دائم، مُنِجةً معرفة نسبية، وأن مفهومي الديني والفلسفي يُقصَد بهما النقل والعقل. وقد أفـاد المرزوقي من ابن خلدون وابن تيمية في استخلاص مفهورٍ يوضح ماهية

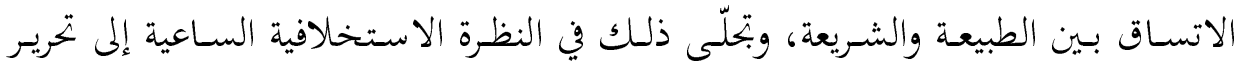

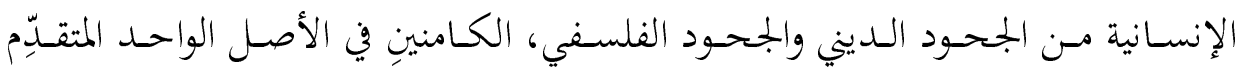

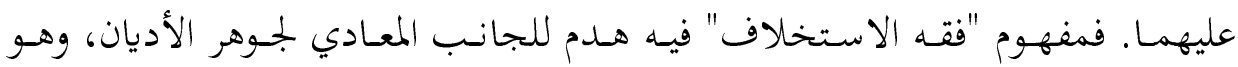

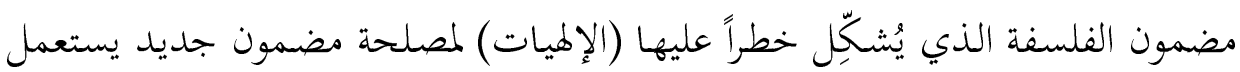

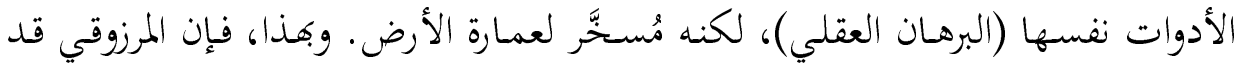
شابه ابن خلدون بتقليصه دور الفلسفة التي تبحث فيما وراء الطبيعة، وتوجيهها لمصلحة علم جديد، هو علم العمران البشري؛ أي إنه استخدم مضمون الفلسفة النقدي في وضع حلولٍ وصياغة مقترحاتٍ لنهوض المجتمعات.

وفيما يخص الجانب المنهجي، فقد طرح المرزوقي منهجية جديدة في علاج التقابل

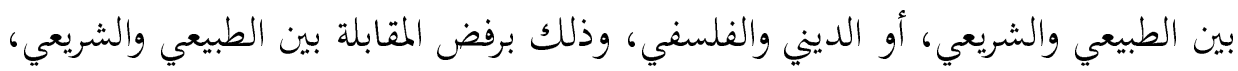

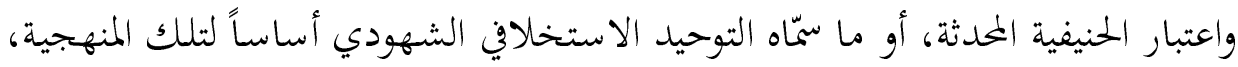

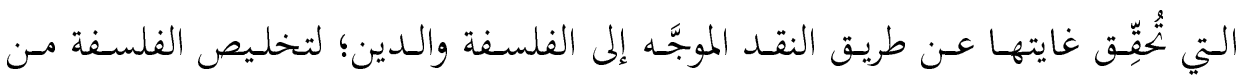

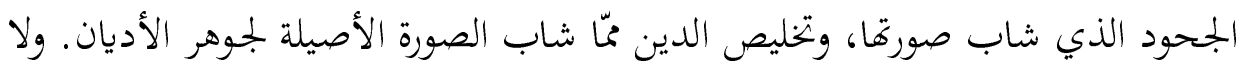
يكون ذلك إلا بالجمع بـين منهجي التحليل والتأويل لتحقيق اللحظة الحاضـة؛ فكالا

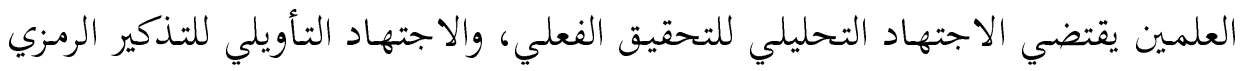

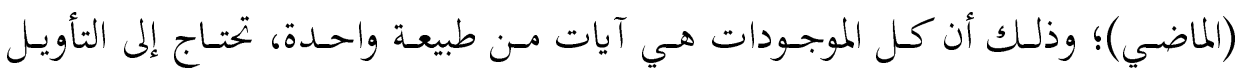

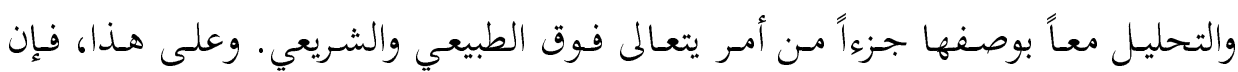

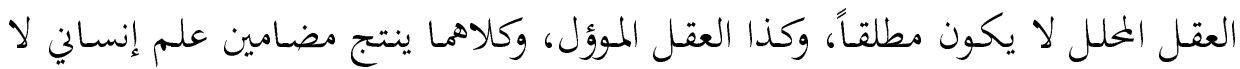

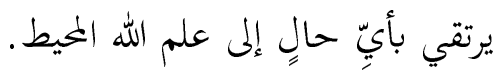

وأمّا الجانب المعري فقد تمثَّل فيما أضافه المرزوقي إلى معارفنا متّا دار حول الثنائيات المتضادة بين الديني والفلسفي، وما انبثق منهما من تفريعات، مثل: الشريعي والطبيعي، 
والشـهود والجحــود، وعبـادة الشـريعة وعبـادة الطبيعـة، ونظريـة الشـرائع ونظريـة الطبائع،

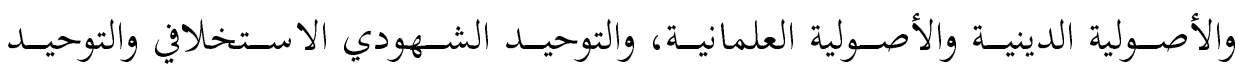

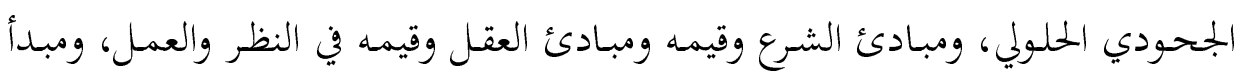

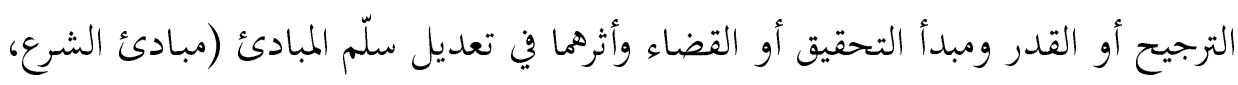

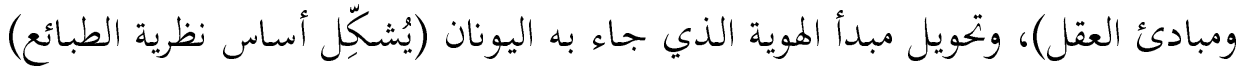

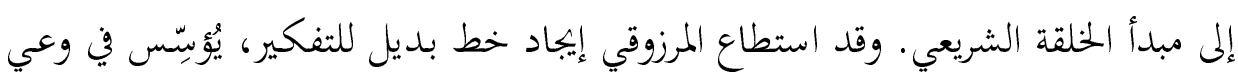

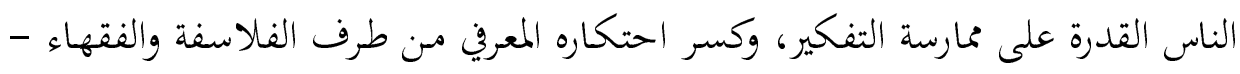

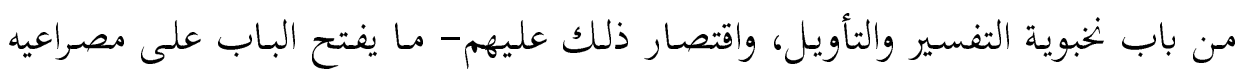

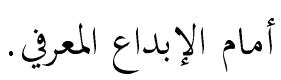

وبعدُ، فإنّا نعود إلى طرح السؤال الأول: هل يمكن اعتبار مشروع المرزوقي في النهضة

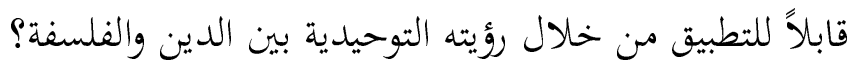
ويبقى هـذا السؤال مشرعاً ينتظر الإجابـة؛ وذلك أن المرزوقي يملك فكراً بتديدياً وتوليـدياً، أنستج الكثـير مـن المفـاهيم والمصسطلحات، وأضساف إليهـا. وهـو فكـر مترامسي

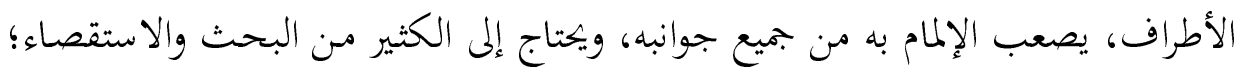

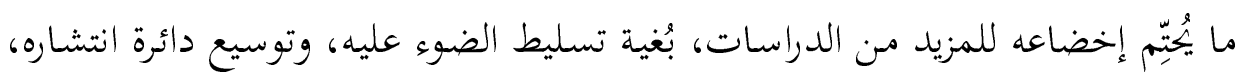

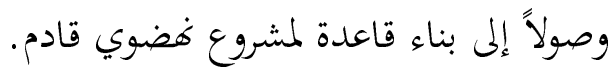

